\title{
GREEN GROWTH OPPORTUNITIES FOR ASIA
}

Sam Fankhauser, Alex Kazaglis, and Sugandha Srivastav

NO. 508

January 2017
ADB ECONOMICS WORKING PAPER SERIES 
ADB Economics Working Paper Series

\section{Green Growth Opportunities for Asia}

Sam Fankhauser, Alex Kazaglis, and Sugandha Srivastav

No. 508 | January 2017
Sam Fankhauser (sam.fankhauser@vivideconomics.com) is an associate director, Alex Kazaglis

(alex.kazaglis@vivideconomics.com) is an engagement manager, and Sugandha Srivastav

(sugandha.srivastav@vivideconomics.com) is an economist with Vivid Economics. 
(c) 2017 Asian Development Bank

6 ADB Avenue, Mandaluyong City, 1550 Metro Manila, Philippines

Tel +632 632 4444; Fax +6326362444

www.adb.org

Some rights reserved. Published in 2017.

Printed in the Philippines.

ISSN 2313-6537 (Print), 2313-6545 (e-ISSN)

Publication Stock No. WPS178639-2

DOI: http://dx.doi.org/10.22617/WPS178639-2

Cataloging-In-Publication Data

Asian Development Bank.

Green Growth Opportunities for Asia.

Mandaluyong City, Philippines: Asian Development Bank, 2017.

1. Climate change. 2. Economic growth. 3. Energy. 4. Environment. 5. Urban development.

I. Asian Development Bank.

The views expressed in this publication are those of the authors and do not necessarily reflect the views and policies of the Asian Development Bank (ADB) or its Board of Governors or the governments they represent.

ADB does not guarantee the accuracy of the data included in this publication and accepts no responsibility for any consequence of their use. The mention of specific companies or products of manufacturers does not imply that they are endorsed or recommended by ADB in preference to others of a similar nature that are not mentioned.

By making any designation of or reference to a particular territory or geographic area, or by using the term "country" in this document, ADB does not intend to make any judgments as to the legal or other status of any territory or area.

This work is available under the Creative Commons Attribution 3.0 IGO license (CC BY 3.0 IGO)

https://creativecommons.org/licenses/by/3.0/igo/. By using the content of this publication, you agree to be bound by the terms of this license.

This CC license does not apply to non-ADB copyright materials in this publication. If the material is attributed to another source, please contact the copyright owner or publisher of that source for permission to reproduce it. $\mathrm{ADB}$ cannot be held liable for any claims that arise as a result of your use of the material.

Attribution-You should always acknowledge ADB as the source using the following format:

[Author]. [Year of publication]. [Title of the work in italics]. [City of publication]: [Publisher]. ( ) ADB. [URL or DOI] [license].

Translations-Any translations you create should carry the following disclaimer:

Originally published by ADB in English under the title [title in italics]. (c) ADB. [URL or DOI] [license]. The quality of the translation and its coherence with the original text is the sole responsibility of the translator. The English original of this work is the only official version.

Adaptations-Any adaptations you create should carry the following disclaimer:

This is an adaptation of an original work titled [title in italics]. (c) ADB. [URL or DOI][license]. The views expressed here are those of the authors and do not necessarily reflect the views and policies of ADB or its Board of Governors or the governments they represent. ADB does not endorse this work or guarantee the accuracy of the data included in this publication and accepts no responsibility for any consequence of their use.

Please contact pubsmarketing@adb.org if you have questions or comments with respect to content, or if you wish to obtain copyright permission for your intended use that does not fall within these terms, or for permission to use the ADB logo.

Notes:

1. In this publication, "\$" refers to US dollars.

2. ADB recognizes "China" as the People's Republic of China and "Korea" as the Republic of Korea.

3. Corrigenda to ADB publications may be found at http://www.adb.org/publications/corrigenda 


\section{CONTENTS}

TABLES, FIGURES, AND BOXES iv

ABSTRACT V v v v v

$\begin{array}{ll}\text { I. INTRODUCTION } & 1\end{array}$

II. WHAT IS GREEN GROWTH?

A. Definition and Rationale 2

B. Operationalizing Green Growth 5

III. HOW BIG IS THE GREEN ECONOMY IN ASIA TODAY? 6

A. $\quad$ Sizing Green Industry 6

B $\quad$ Green Industry in Asia Today $\quad 7$

IV. HOW BIG COULD THE GREEN ECONOMY BE IN ASIA TOMORROW?

A. Estimating the Future Green Industry 9

B. Asia's Potential in the Green Economy 12

V. POLICIES FOR PURSUING GREEN GROWTH 22

VI. CONCLUSIONS

$\begin{array}{ll}\text { REFERENCES } & 27\end{array}$ 


\section{TABLES, FIGURES, AND BOXES}

\section{TABLES}

1 Definitions of Green Growth

2 Indicators of Green Growth

\section{FIGURES}

$1 \quad$ Low-Carbon Environmental Goods and Services Sales $\quad 7$

2 Largest Absolute Value of Low-Carbon Environmental Goods and Services 8

3 Share of Global CCMT Exports 8

$4 \quad$ Number of High-Value CCMT Patents in 2012

5 Innovation Specialization and Revealed Comparative Advantage in CCMTs 12

6 Asia's Key Strengths and Opportunities 13

$7 \quad$ Leading Exporters in CCMT 14

8 The People's Republic of China's Strengths by Technology 15

$9 \mathrm{CO}_{2}$ Productivity Levels in Asia 16

10 Share of Renewables in Electricity Generation 17

11 Share of Green Innovation in India 19

12 The Republic of Korea's Strengths by Technology 20

13 Top Innovators in CCMTs 21

14 Japanese Climate Change Mitigation Patents 21

15 Japan's Strengths by Technology $\quad 22$

16 Asia's Key Strengths, Weaknesses, Opportunities, and Threats in CCMTs 26

\section{BOXES}

$1 \quad$ The Green Innovation Index 10

2 The Index of Revealed Comparative Advantage 11 


\begin{abstract}
This paper assesses the low-carbon economy in Asia: how large it is today and how well it will fare in the future. Using patent and trade data, it analyzes the potential of Asian economies to capture value from the design and export of low-carbon technologies, acknowledging that these are only two dimensions of a multidimensional low-carbon economy. It conducts country-level analysis to identify which technologies different countries can specialize in and potentially scale up. The work shows that, overall, Asia has an innovation specialization and revealed comparative advantage in climate change mitigation technologies. Particular strengths include efficient lighting, photovoltaics, and energy storage technologies. Further opportunities include nuclear and smart grids. However, within Asia, there are regional disparities, with countries such as the People's Republic of China, Japan, and the Republic of Korea outperforming others. This paper highlights how the analytical framework it presents can be used to strategically inform environmental policy makers and concludes with an overview of the green growth policy tool kit.
\end{abstract}

Keywords: climate change, economic growth, energy, environment, urban development

JEL codes: Q42, Q43, Q54, Q56 


\section{INTRODUCTION}

Every economist knows that gross domestic product (GDP) is an inaccurate measure of human welfare. Its proponents will point out that GDP is correlated positively with many dimensions of human welfare and is therefore a reasonable proxy for the things society cares about. However, in the case of the natural environment, that correlation is far from perfect. In fact, an increase in economic activity is often associated with a decrease in environmental quality. Air pollution in the booming cities of developing Asia is a clear case in point.

Environmental economists have therefore devised green alternatives to the traditional macroeconomic indicators, which begin to reflect the state of the environment in the national accounts (World Bank 2013). The new indicators are derived from the notion of sustainable development, defined by the World Commission on Environment and Development (1987) as "development which meets the needs of current generations without compromising the ability of future generations to meet their own needs." For economists, sustainable development means that the total stock of productive capital in an economy-physical, human, and natural-must remain constant over time.

The pursuit of green growth is a direct response to these insights. Its aim is to increase economic activity while protecting natural assets for future generations to survive and thrive. More so than sustainable development, green growth emphasizes the possibility, indeed the desirability, of pursuing economic growth and environmental protection at the same time (Jacobs 2012). It gained prominence in the aftermath of the 2008 financial crisis as a response to the perception that economic recovery should take precedence over environmental preservation. Green growth proponents countered that the two must in fact go hand in hand (Bowen and Stern 2010; Barbier 2010). They can point to a global green economy that is rapidly expanding and performing stronger than many conventional sectors. However, commentators also point out the radical policy shifts that are required to make green growth a reality (Bowen, Duffy, and Fankhauser 2016).

Asian countries have been among the first to understand the potential of, and the need for, green growth. The Republic of Korea passed a framework law on "low-carbon green growth" in 2009. The People's Republic of China (PRC) has made the promotion of key green economy sectors, such as clean transport, a strategic objective of its 5-year plans (Townshend et al. 2011). These are deliberate attempts to position Asian economies at the forefront of the emerging green economy.

This paper explores the potential for green growth in Asia. Asian countries are well positioned to prosper in the green economy. As we set out in the following, Asia is already performing well in an international context. Asian countries are among the world's leading producers of green goods and services. They have significant comparative advantages in key technologies, such as energy storage, and they are strong innovators in areas such as biofuels, nuclear technology, and clean transport. However, further policy incentives will arguably be needed to realize this potential.

For data reasons, the paper focuses on one particular aspect of green growth: low-carbon growth. The business of reducing greenhouse gas (GHG) emissions is probably the most prominent aspect of green economic growth to date. However, it is worth emphasizing the comprehensive nature of green growth, which is not just low carbon, but also climate resilient, biodiverse, clean, and sustainable (Bowen and Fankhauser 2011). 
The paper is structured as follows. Section II reviews the economic literature on green growth and defines the concept. Section III provides estimates of the size of Asia's low-carbon economy today. Section IV sets out the opportunities and threats for low-carbon growth in Asia in the future. Section $V$ sets out the policy interventions required to realize these opportunities. Section VI concludes.

\section{WHAT IS GREEN GROWTH?}

This section provides a definition and sets out the rationale for green growth. It covers relatively recent literature, and many of the assertions made about the mechanisms and benefits of green growth are awaiting further empirical corroboration. Nevertheless, they are presented here to highlight the most up-to-date thinking in the field.

\section{A. Definition and Rationale}

Green growth proponents have a common worldview that it is possible to be green and to grow at the same time. Beyond this shared expectation, there are nuances in emphasis and interpretation. Jacobs (2012) distinguishes between a "standard" interpretation of green growth, which emphasizes the longrun economic benefit of environmental protection and the bolder assertion that environmental policy can be a driver for growth.

Returning to the basic tenets of sustainable development, Bowen and Hepburn (2014) define green growth as an increase in economic activity in the long term, and possibly short term, without reducing aggregate natural capital. Other definitions of green growth acknowledge the importance of alternative measures of progress such as welfare, quality of life, and resilience to extreme weather events. 0 shows how different institutions have defined green growth.

Table 1: Definitions of Green Growth

\begin{tabular}{ll}
\hline Institution & Definition \\
\hline Asian Development Bank (ADB) & $\begin{array}{l}\text { Low-carbon green growth is a pattern of development that } \\
\text { promotes growth through the creation of new environment- } \\
\text { friendly products, industries, and business models that also } \\
\text { improve people's quality of life. }\end{array}$ \\
$\begin{array}{ll}\text { Organisation for Economic Co-operation and Development } \\
\text { (OECD) }\end{array}$ & $\begin{array}{l}\text { Economic growth and development that ensures natural } \\
\text { assets continue to provide the resources and environmental } \\
\text { services on which our well-being relies. }\end{array}$ \\
& $\begin{array}{l}\text { Growth that is efficient in its use of natural resources, clean } \\
\text { in that it minimizes pollution and environmental impacts, } \\
\text { and resilient in that it accounts for natural hazards and the } \\
\text { role of environmental management and natural capital in } \\
\text { preventing physical disasters. And this growth needs to be } \\
\text { inclusive. }\end{array}$ \\
\hline
\end{tabular}

Sources: Asian Development Bank Institute. 2012. Policies and Practices for Low-Carbon Green Growth in Asia. Tokyo; Organisation for Economic Co-operation and Development. 2011. Towards Green Growth. Paris; World Bank. 2012. Inclusive Green Growth: The Pathway to Sustainable Development. Washington, DC. 
The concept of green growth is not uncontroversial. Some argue that there is no evidence that economic activity and environmental pressure can be comprehensively decoupled (Jackson 2011; Klein 2015), while others argue that the historical record of increasing resource use with GDP growth is not necessarily a guide to the future and that some forms of environmental damage have slowed with increased income levels (Bowen and Hepburn 2014).

The theoretical arguments in favor of green growth are anchored in three key notions: the need for natural capital preservation, the dynamic externalities of (clean) innovation, and the economic benefits of correcting market failure. The argument is that green policies can preserve valuable stocks of natural capital, create structurally higher rates of innovation, and internalize externalities to correct for the overprovision of polluting goods and the underprovision of green goods (Bowen and Fankhauser 2011)

\section{Economic Rationale 1}

Green policies can maintain and appreciate natural capital stocks, which are valuable inputs to production and welfare. This is grounded in Hotelling's (1931) insights on the value of nonrenewable stocks, which can be applied to all natural resources.

The first of the three notions - the need to preserve natural capital stocks-follows directly from the economics of sustainable development (Solow 1974, Hartwick 1977), which in turn is based on Hotelling's seminal work on natural resource management. Solow (1974) and Hartwick (1977) demonstrated that in order to ensure a nondecreasing level of utility over time (i.e., to make sure future generations are no worse off than today's), the rents from natural resource extraction have to be reinvested into other forms of capital so that the overall stock of capital remains constant.

This implies that there are in fact three types of capital that society needs to manage: economic, human, and natural. The three forms are not necessarily perfect substitutes. Some forms of natural capital in particular may be irreplaceable. Society cannot live without nature (Spash 2008). The nonsubstitutability of some forms of natural capital and irreversibility of particular activities (e.g., reduction of biodiversity and extinction of natural populations) is an important qualification to the sustainability rules of Hartwick (1977) and Solow (1974).

Nature's contribution to human welfare is complex. The economic theory of ecosystem services distinguishes between provisioning services (food, water, and materials), cultural services (spiritual value, recreation, and mental and physical health), regulating services (air quality, water treatment, and carbon sequestration), and support services (genetic diversity and habitats). The full extent of this rich range of services is not always appreciated by policy makers.

\section{Economic Rationale 2}

Green policies can create a structurally higher rate of innovation, based on the Schumpeterian (1942) view of the fundamental role of innovation in value creation.

The second rationale for green growth is the dynamic externalities of innovation. Schumpeter (1942) argued that innovation is at the root of long-run growth and the key to economic development. In the absence of innovation, a stationary state could ensue. Schumpeter described the nature of innovation according to cycles of creative destruction, where innovators disturb the existing system 
and create the conditions for further innovation, learning, and growth as conventional technologies become outmoded.

The Schumpeterian lens is supported by the work of Fouquet and Pearson (2012) on innovation in the transformation of energy into light, and Perez (2002) on technological revolutions more broadly. Looking at lighting technology and consumer behavior over a 200-year period, Fouquet and Pearson (2012) found that the productivity gains associated with improvements in the technology contributed not just to increases in living standards, but also increased demand for energy to cover basic needs, further contributing to growth. Looking at technological revolutions in general since the beginning of the industrial revolution, Perez (2002) shows that boom and bust cycles are an endogenous part of the market capitalist system. Projecting forward, she sees the potential conditions for a Sustainable Global Golden Age with green outcomes providing the overall direction for innovation.

There is evidence that green technologies are inherently more innovative than others and create higher spillovers. Dechezleprêtre, Martin, and Mohnen (2013) show that green patents are cited more commonly and by more prominent patents than brown technologies. Green spillover effects are on a par with those of transformative new innovations such as information technology and nanotechnology. Research further shows that an increase in market size may lead to further innovation and demand externalities, that is, the growth in the green economy of one country can incentivize innovation in other countries (Acemoglu and Linn 2004).

\section{Economic Rationale 3}

Green policies can maximize welfare by pricing negative externalities such as air and carbon pollution, as demonstrated by Pigou (1920).

The third rationale is related to externalities and market failures, which impose an economic cost in conventional economic models. This rationale goes back to the work of Pigou (1920), who was an early proponent of internalizing external costs.

Currently, the social value of natural capital and ecosystem services is not accurately or adequately reflected in prices. This means that the market mechanism fails to account for third-party environmental costs and benefits of certain activities creating "externalities." For example, industrial processes can pollute surrounding areas and disrupt the provision of valuable ecosystem services such as freshwater to the local community. This is a negative externality which typically results in the overprovision of goods and services that pollute the environment. Conversely, maintaining public areas such as local parks carry positive externalities in the form of fresh air and recreation. However, such goods are typically underprovided since it is difficult to monetize their benefits.

Environmental externalities are not the only market failures that green growth may overcome. There are also market imperfections related to networks, capital markets, clean innovation, and the provision of information. Behavioral barriers and policy distortions, such as the underpricing of energy and water, hold back the adoption of resource efficiency measures. The International Monetary Fund estimates that the combination of energy subsidies and energy-related externalities (e.g., air pollution) amounts to a global cost of $\$ 5.3$ trillion, that is, around 6.5\% of global GDP (Coady et al. 2015). 


\section{B. Operationalizing Green Growth}

Clearly specified objectives and methods to track progress are required to design and implement effective green growth policy. The objectives of green growth start with economic growth through green industry. Green industry includes energy-efficient modes of production, goods and services for pollution control and abatement, and renewable energy. However, green growth aims to achieve objectives beyond simply growing green industry. Green growth also entails the recognition of ecosystem services, such as adequate access to food and clean water, climate regulation, and recreational benefits, given that these are of social value.

Green growth poses a challenge for conventional indicators of economic performance, such as GDP, which do not provide a good report of performance across green industry, natural capital, and ecosystem services (Green Growth Knowledge Platform 2013). National accounts data commonly do not include natural capital assets and ecosystem services even though they provide goods and services that are captured in GDP. For example, natural resources such as timber and fossil fuels contribute to GDP through activities in the construction sector, while ecosystem services such as regulating the climate are captured in agricultural output. Since the economic and social value of natural capital and ecosystem services is not measured, efforts to preserve nature such as cleaning up pollution, appear as a net cost rather than a benefit.

International efforts by the Organisation for Economic Co-operation and Development (OECD), the World Bank, and others to measure green growth and the size of the green economy provide a more comprehensive account of progress. The OECD green growth measurement framework aims to develop a common set of metrics to assess green growth that includes natural capital, ecosystem services, and economic transitions (Table 2). Progress has also been made in incorporating ecosystem services into economic policy decisions. Programs on wealth accounting and natural capital accounting are emerging, including for example in the Philippines and Indonesia.' There are also efforts to establish a global standard for natural capital valuation, such as The Economics of Ecosystems and Biodiversity.

Table 2: Indicators of Green Growth

\begin{tabular}{lll}
\hline Theme & & Sample Indicators \\
\hline Green growth/green economy & - & green jobs \\
policies and opportunities & - & green financial flows \\
& - & environmental tax revenue \\
\hline Environmental life quality and & - & population exposure to harmful levels of air pollution \\
safety & - & population with sustainable access to safe drinking water \\
\hline Environmental and resource & - & research and development expenditure/number of patents \\
productivity & & important to green growth \\
& - & domestic material productivity at appropriate level of aggregation \\
& - & gross domestic product per unit of energy-related $\mathrm{CO}_{2}$ emissions \\
\hline Natural asset base & - & proportion of fish stocks within safe biological limits \\
& - & area and volume of forests \\
& - & proportion of agricultural area with severely degraded soil \\
\hline $\mathrm{CO}_{2}=$ carbon dioxide. &
\end{tabular}

1 See Wealth Accounting and the Valuation of Ecosystem Services. https://www.wavespartnership.org/ 
While these frameworks are comprehensive, multiple indicators are challenging to track and must be interpreted with caution. Limited geographic coverage of data sets, such as valuing natural capital stocks, make cross-country comparisons difficult. Monetizing benefits from ecosystem services requires the application of methods that rely on subjective reporting such as contingent valuation. In attempting a cross-country comparison, it may therefore be appropriate to focus on a limited set of indicators for which data are available and sufficiently robust.

\section{HOW BIG IS THE GREEN ECONOMY IN ASIA TODAY?}

This section applies the concept of green growth to Asia. It assesses the size of Asia's "green economy" and compares it with other continents, particularly Europe and Latin America. As discussed earlier, "green growth" has several components. For the purpose of this section, we will specifically concentrate on low-carbon growth and the development of green technologies that help decouple economic output from carbon dioxide $\left(\mathrm{CO}_{2}\right)$ emissions. While low-carbon growth is a subset of green growth, it is a useful indicator of the size of the overall green economy.

\section{A. Sizing Green Industry}

There is some degree of flexibility in defining the green economy. In a low-carbon context, the most stringent definition would claim that an industry is green if production results in zero emissions. A less stringent definition would argue that an industry is green if it produces "acceptable levels" of emissions that meet climate change policy targets.

Early efforts at sizing the green economy often overlooked green activity in nonenvironmental sectors. The OECD (1998) was one such attempt, which focused on a limited set of sectors involved in environmental protection, such as wastewater treatment and air pollution control. Defining environmental sectors in this way omits specialized firms that supply the green economy but sit outside sectors classified as green (OECD 1998). For example, technologies that improve energy or resource efficiency are not explicitly designed for environmental purposes but can, nevertheless, be included in the measurement of the green industry. Furthermore, dichotomously labeling sectors as "green" or "gray" runs the risk of ignoring green installations within "gray" sectors (Fankhauser et al. 2013). Research by HSBC (2009) shows that the majority of green revenue does not accrue in explicitly green sectors.

To ensure that green establishments in gray sectors are not overlooked, the United Kingdom Department for Business, Innovation and Skills developed a new sectoral classification in 2011 which defines a set of "environmental sectors" whose activities cut across conventional sectors. For example, "air pollution" is a sector in the Low-Carbon Environmental Goods and Services (LCEGS) data set whose activities cut across agriculture, manufacturing, and services. The use of sales data, rather than value added, allows for more of the green industry to be captured in measurements, since a significant proportion of green activity, such as pollution control, happens in the operational stages. The LCEGS data are sales data on green operations and technologies, rather than just final goods. As such, the LCEGS data set includes both supply and value chain activities (UK Department for Business, Innovation and Skills 2011). 


\section{B. Green Industry in Asia Today}

We can use data on sales of green technologies and activities to conduct a comparative analysis of the current size of the green industry in Asia. We use LCEGS sales, which is well designed for this purpose due to its global and green activity coverage. We also use trade and patent data on climate change mitigation technologies (CCMT) in section IV.

The key conclusions from this analysis, broken by data type, are the following:

(i) Sales. Asia has the largest value of green sales compared with other continents. Within Asia, the PRC has the largest value of green sales per unit of GDP, and is second globally to the United States (US).

(ii) Exports. Asia accounts for a higher share of global CCMT exports than Europe and Latin America. Within Asia, the PRC exports more CCMTs than other countries.

(iii) Innovation. In 2012, Asia filed more high-value CCMT patents than Europe and Latin America. The Republic of Korea and Japan are Asia's leading innovators according to the European Patent Office data set.

According to the LCEGS data, Asia has the largest value of green sales in absolute terms and per unit of GDP, compared with other continents (see Figure 1).

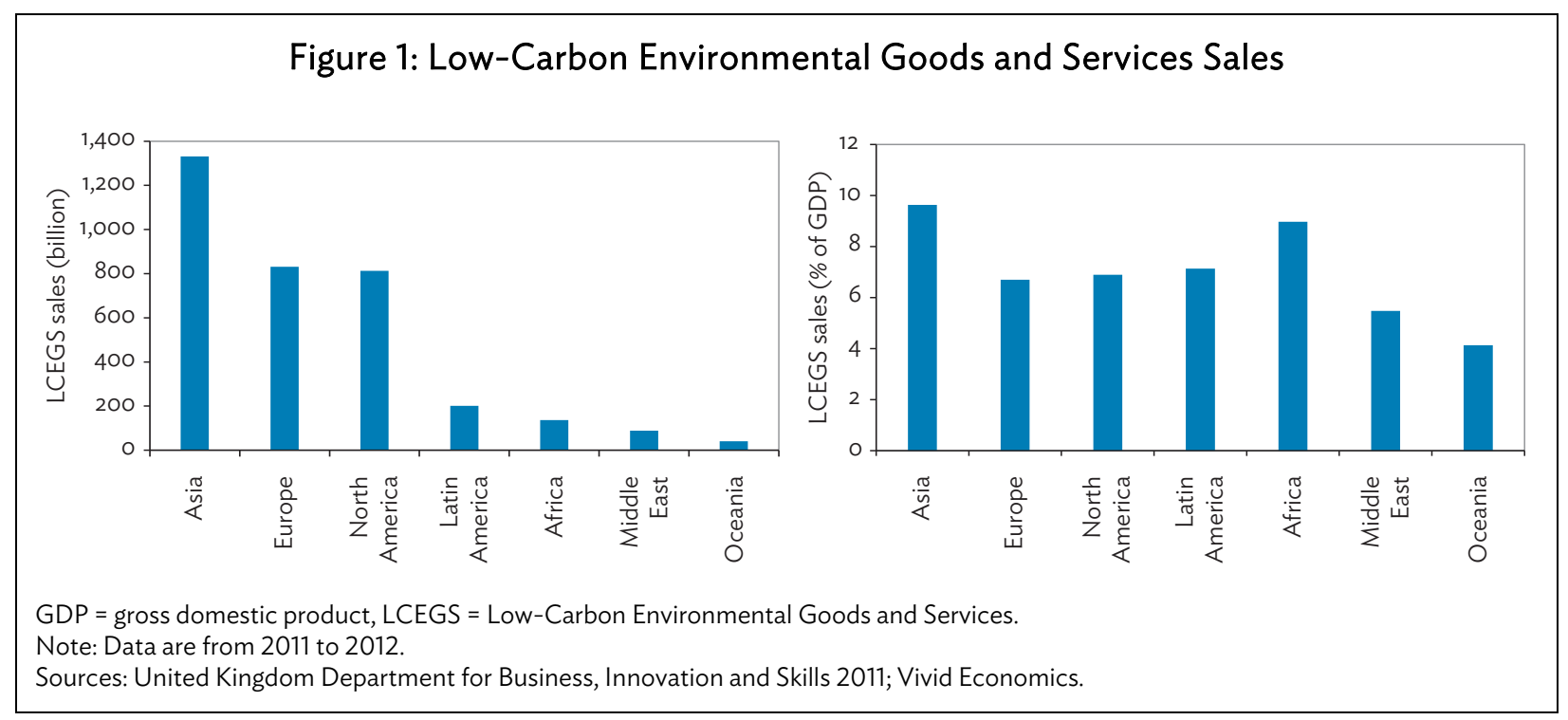

Within Asia, the PRC has the largest market share (Figure 2). This is to be expected given the dominant size of its economy. Relative to GDP, the Philippines has the highest value of LCEGS sales, followed by India. In both of these countries, LCEGS sales are worth approximately a fifth of GDP, while in the PRC they are a tenth. Globally, the top five countries in terms of absolute value of LCEGS sales are the US, the PRC, Japan, India, Germany, and the United Kingdom, in that order.

Asia accounts for a higher share of global CCMT exports than Europe and Latin America. As Figure 3 shows, Asia already accounts for $44 \%$ of global climate change mitigation exports. Within Asia, the PRC accounts for $20 \%$ of global CCMT exports (Figure 3). The PRC's strongest exports are efficient lighting and photovoltaics. 
Figure 2: Largest Absolute Value of Low-Carbon Environmental Goods and Services
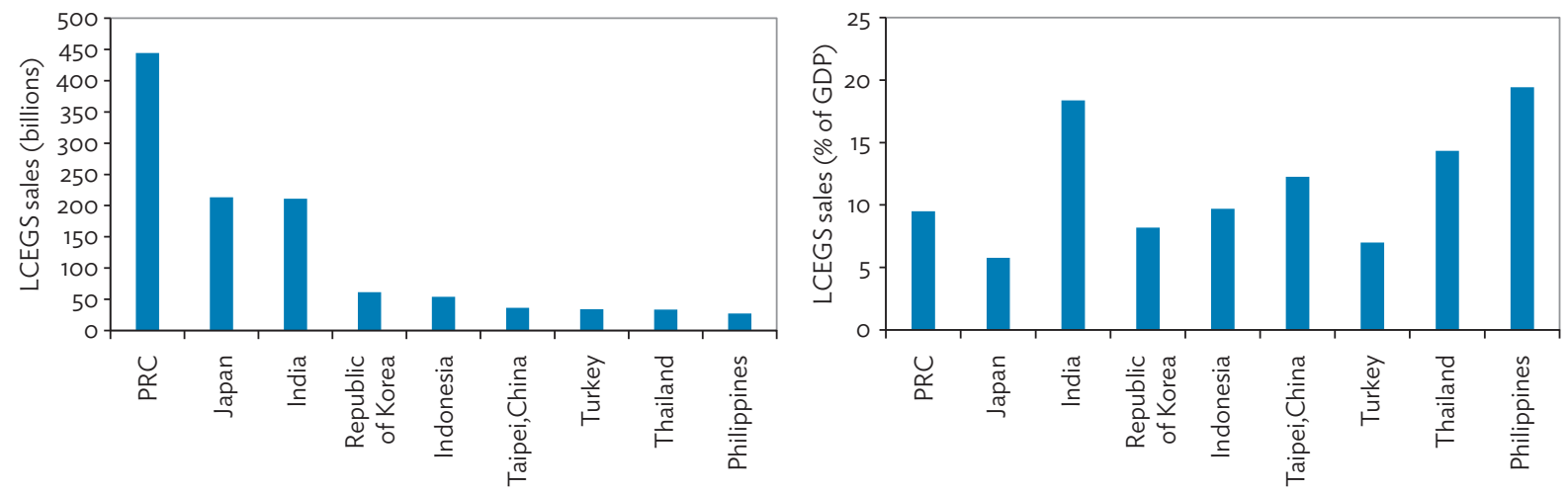

GDP = gross domestic product, LCEGS = Low-Carbon Environmental Goods and Services, PRC = People's Republic of China. Note: Data are from 2011 to 2012.

Sources: United Kingdom Department for Business, Innovation and Skills 2011; Vivid Economics.

Figure 3: Share of Global CCMT Exports
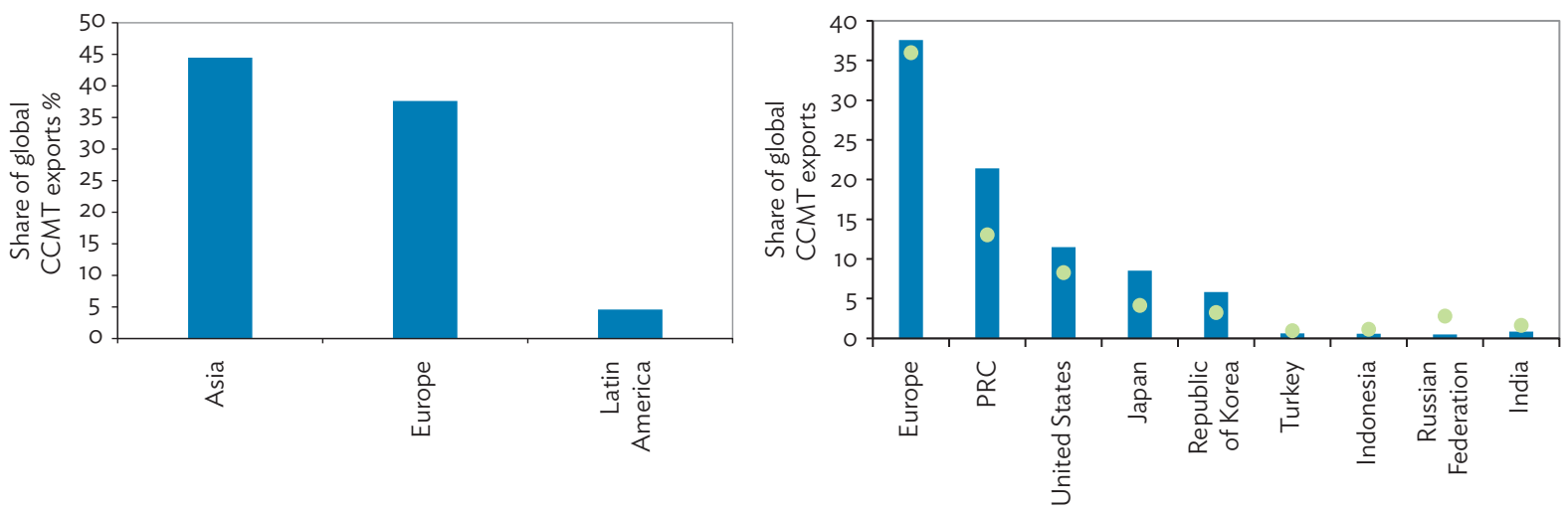

CCMT = climate change mitigation technologies, PRC = People's Republic of China.

Notes: The circles indicate share of total global exports; 2013 data.

Sources: United Nations Commodity Trade Statistics Database (UN Comtrade); Vivid Economics.

In 2012, Asia filed more high-value CCMT patents than either Europe or Latin America (Figure 4). As mentioned, the Republic of Korea and Japan are Asia's leading innovators. Japan is the leading innovator in green transport, while the Republic of Korea is the leading innovator in energy storage. Both countries also have relatively high levels of patenting activity in photovoltaics. 


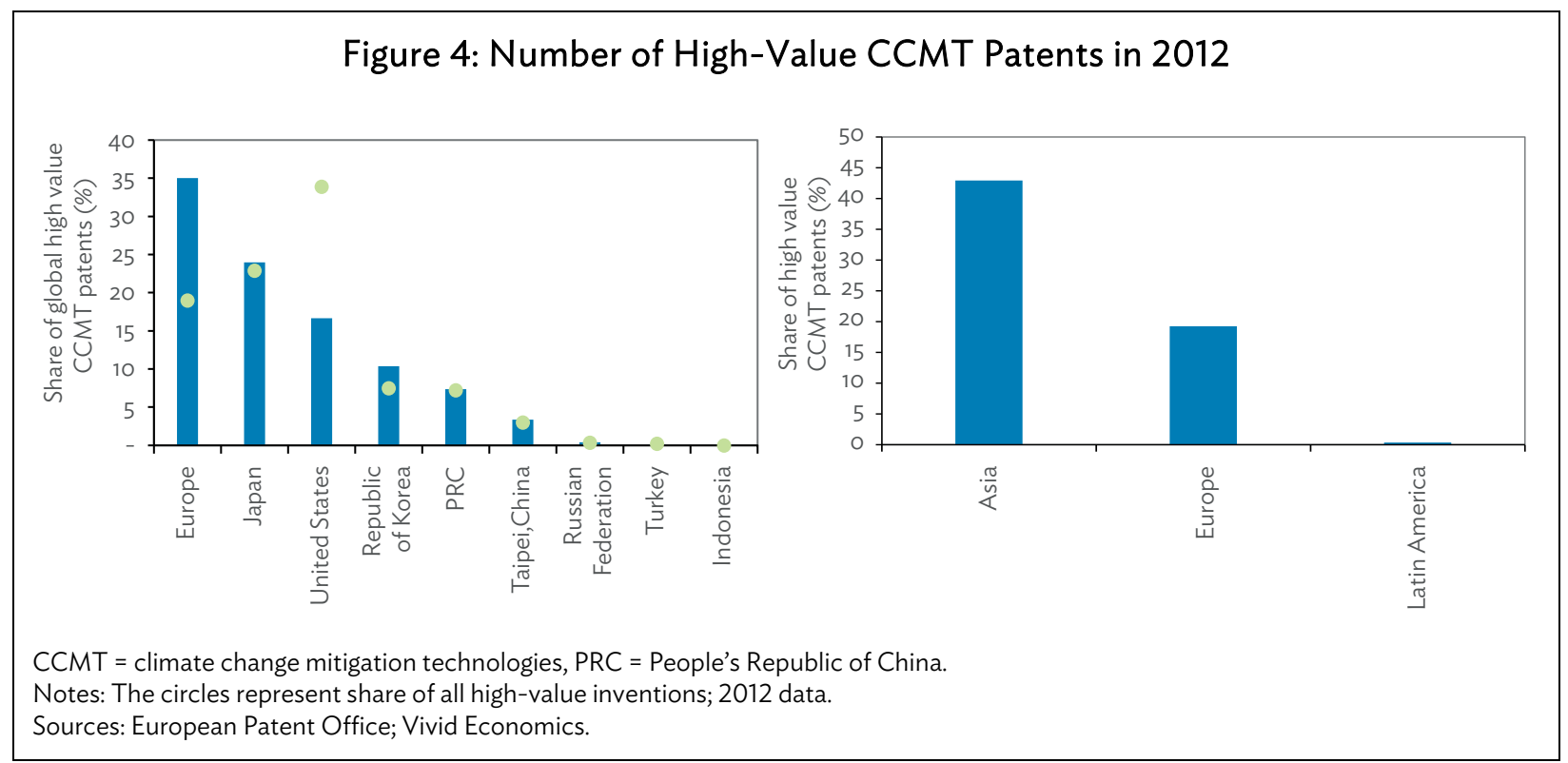

\section{HOW BIG COULD THE GREEN ECONOMY BE IN ASIA TOMORROW?}

The fact that Asia's green economy is performing well today does not necessarily mean its place is assured as a global leader in the green race. In this section, we investigate how well placed Asia is to capture value from the future green economy by looking at the level of innovation and degree of trade specialization in key low-carbon technologies.

\section{A. Estimating the Future Green Industry}

We estimate the future size of the green economy using a methodology developed in Fankhauser et al. (2013). Specifically, we calculate for each green sector two indicators associated with green economic potential.

The first indicator is a measure of innovation specialization, labeled the green innovation index (GII). The GIl employs patent data to indicate whether a country "specializes" in innovating a technology. If the country has an "innovation specialization," it has promising long-term prospects of becoming a global innovation leader in that technology. This corresponds to opportunities related to capturing value from the design and manufacture of low-carbon technologies, since there are incentives to locate manufacturing close to the area of innovation (e.g., protection of intellectual property) (see Box 1).

The second indicator measures comparative advantage, using a standard Balassa index of revealed comparative advantage ( $R C A$ ). The Balassa index employs trade data to assess whether economies have a current specialization in low-carbon technologies. On the assumption that comparative advantages develop slowly, sectors with a competitive edge today are likely to be internationally competitive also in the future and able to capture global market share (see Box 2). 


\section{Box 1: The Green Innovation Index}

The green innovation index (GII) is a measure of a country's green innovation performance in a sector. The GII is defined as:

$$
G I I_{i s}=\frac{p_{i s}^{g} / p_{i s}}{\sum_{i} p_{i s}^{g} / p_{i s}}
$$

where $p_{i s}^{g}$ is the number of green patents and $p_{i s}$ is the total number of patents in sector $s$ and country $i$. The GII divides a technology's share of patents in a country over that technology's share of patents in the world. Normalizing against broader patenting activity corrects for idiosyncrasies in patenting behavior in particular sectors or countries (Fankhauser et al. 2013).

Different values of the GIl can be interpreted in the following manner, for a given technology:

- $\quad$ Gll = 1 implies that the country has no particular advantage or disadvantage over the rest of the world with regard to innovation. The share of patents in the country is equal to the global average.

- $\quad$ GII > 1 implies that the country specializes in innovating the technology. The share of patents in the country exceeds the global average. This corresponds to better long-term prospects of capturing value from design.

- Gll $<1$ implies that a country is less well placed compared with the global average in innovating in the technology.

In constructing the index, only high-value patents are considered. We define a high-value patent as one that has been filed in two geographies. The rationale for this is that in certain countries, companies file low-value patents to garner government support since funding may be contingent on patent activity. Since it is costly to file patents, filing in a second territory indicates that the inventor believes that their invention has value and can gain return in more than one market. While this is an imperfect proxy for value, it is one that is commonly used across patent literature (Dechezleprêtre and Martin 2010).

Patent documents offer an indication of innovative capacity and also may give an indirect indication as to where future manufacturing of these technologies may take place. However, there are some drawbacks. The region of manufacturing depends on a wide range of factors including labor costs, opportunities to exploit economies to scale, and proximity to customers, so the link between patenting location and future manufacturing location may not be strong. Another drawback of patent data is that they do not give an indication of the value of a technology to an economy, so many patents may not necessarily correspond to a large potential value, although we have attempted to mitigate this effect by only considering patents that have been filed in at least two locations. Finally, patent data often ignore incremental or processoriented innovation which occurs across several Asian countries. Notwithstanding these drawbacks, patents do provide some indication of innovative capacity, and the widespread availability of data makes them well suited to cross-country analysis.

Sources: Fankhauser, Sam, Alex Bowen, Raphael Calel, Antoine Dechezleprêtre, David Grover, James Rydge, and Misato Sato. 2013. "Who Will Win the Green Race? In Search of Environmental Competitiveness and Innovation." Global Environmental Change 23 (5): $902-$ 13; Dechezleprêtre, Antoine, and Ralf Martin. 2010. "Low Carbon Innovation in the UK: Evidence from Patent Data." Policy Paper. Grantham Research Institute on Climate Change and Environment Centre for Climate Change Economics and Policy. 


\section{Box 2: The Index of Revealed Comparative Advantage}

The index of revealed comparative advantage (RCA) is a measure for the comparative advantage in a sector. The RCA divides a sector's share of exports in a country over that sector's share of exports in the world:

$$
R C A_{i s}=\frac{e_{i s} / \sum_{s} e_{i s}}{\sum_{i}{ }^{e_{i s}} / \sum_{s} \sum_{i} e_{i s}},
$$

where $e_{i s}$ is the level of exports from sector s in country $i$.

The RCA has following interpretations interpretation, for a given technology:

- $\quad$ RCA $=1$ implies that the country has no particular export advantage or disadvantage over the rest of the world. The share of exports in the country is equal to the global average.

- $\quad$ RCA > 1 implies that the country specializes in exporting that technology. This is likely to correspond to better long-term prospects of capturing global market share and value from trade and manufacturing.

- $\quad$ RCA $<1$ implies that a country is at an export disadvantage as the share of exports in the country is below the global average.

The advantage of looking at RCA is that it adjusts for size of the economy to pinpoint comparative advantage and indicate specialization prospects. The disadvantage is that since opportunity costs cannot be directly inferred, we can at best say that higher RCA is likely to correspond to lower opportunity costs, but this is not a given, since government intervention and other factors can also lead to a high RCA.

Source: Fankhauser, Sam, Alex Bowen, Raphael Calel, Antoine Dechezleprêtre, David Grover, James Rydge, and Misato Sato. 2013. "Who Will Win the Green Race? In Search of Environmental Competitiveness and Innovation." Global Environmental Change 23 (5): $902-13$.

Placing the green innovation index and Balassa index on the $y$ and $x$ axes of a plane, respectively, provides the basis for a SWOT (strengths, weaknesses, opportunities, and threats) analysis:

(i) The top right corner of such a plane corresponds to better green growth prospects (i.e., strengths); a sector is innovating from a current position of competitive strength.

(ii) The bottom left would be the opposite (i.e., weaknesses); a sector exhibits strength in neither innovation nor its current export position.

(iii) The top left quadrant corresponds to opportunities; a sector scores well on innovation but poorly on comparative advantage. This is an opportunity because the country can exploit its innovation to spur manufacturing and export in the sector.

(iv) The bottom right quadrant corresponds to threats; a sector scores poorly on innovation but well in comparative advantage. This is a threat because it is possible that once the technology paradigm changes, that country's market for that technology becomes outdated, controlling for other factors.

It is important to note that these are only two dimensions of a multidimensional set of green growth indicators. Two important dimensions that are missing are technology adoption (as opposed to innovation) and domestic scale. It may be possible that a country does not innovate in a technology but still becomes a leading manufacturer in it. Often this is because of other factors such as proximity to a large consumer base and cost competitiveness in manufacturing. Countries such as the PRC are a case in point. The PRC, which has historically been an early adopter rather than an innovator and has a large domestic market, is well poised for green growth due to agglomeration benefits and demand externalities associated with large domestic scale. This potential is overlooked in our two-dimensional framework, as we will see. 


\section{B. Asia's Potential in the Green Economy}

A substantial and thriving green economy already exists in Asia, with Asian companies playing important roles. Global sales of green goods and services amount to $\$ 2.9$ trillion a year (FTSE 2016). Developing Asia as a whole accounts for $22 \%$ of global high-value CCMT patents and 35\% of exports.

Asia has an RCA and innovation specialization in CCMTs. As Figure 5 demonstrates, the PRC, Japan, and the Republic of Korea are key exporters and innovators in CCMTs and account for a large share of Asia's export and high-value patenting activity. This is a strong indicator of the region's potential, as more innovative economies are likely to be better placed to capture markets in new technologies. Although countries such as India, the Philippines, and Viet Nam are not frontier innovators in CCMTs, they often undertake incremental innovation which is not captured by our data. Developing Asian countries have a strong comparative advantage in certain CCMTs, such as photovoltaics, as explained in the country profiles.

Overall, Asia's position as an exporter of CCMTs is stronger than its position as an innovator. Asia is on track to capture value from the design and export of key CCMTs such as energy storage, photovoltaics, and efficient lighting. However, there is room for growth by developing specializations in additional CCMTs, ensuring the green economy transformation is occurring equally across all Asian countries, and further advancing policies to enable this transformation (see section VI for a summary assessment).

Figure 5: Innovation Specialization and Revealed Comparative Advantage in CCMTs

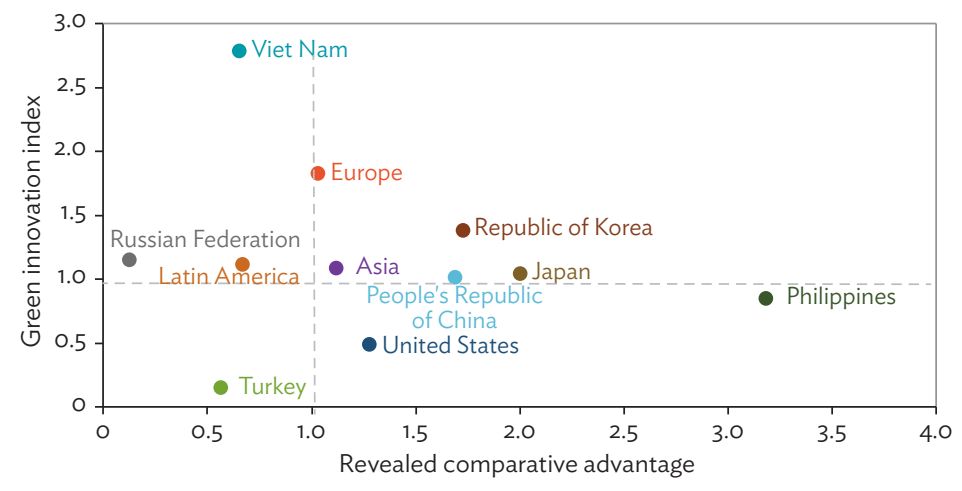

CCMT = climate change mitigation technologies .

Notes: 2012 data for green innovation index (GII) and revealed comparative advantage (RCA). For the GII, regional CCMT patenting activity is normalized by the share of global patenting activity. Apart from Viet Nam and the Philippines, all regions have a share of global patenting activity that exceeds $0.4 \%$. A low normalizing factor explains Viet Nam's high score on the GII. Similarly, for RCA, all regions have an export share that exceeds $1 \%$ of global exports apart from the Philippines, which explains its high RCA score. Results for such countries should be interpreted with caution.

Sources: International Energy Agency; United Nations Commodity Trade Statistics Database (UN Comtrade); European Patent Office; Vivid Economics.

Breaking down Asia's strengths by technology (Figure 6) suggests that Asia's core strength is in efficient lighting, photovoltaics, and energy storage where it has both an innovation and export specialization. It is also worth mentioning that Asia has consolidated its position as the world's top 
exporter in photovoltaics. The Republic of Korea leads in patents for energy storage technology. India shows significant potential for incremental innovation by adapting existing technologies like wind power and smart grids to local needs. The Philippines excels in a number of low-carbon metrics and exhibits a comparative advantage in efficient lighting.

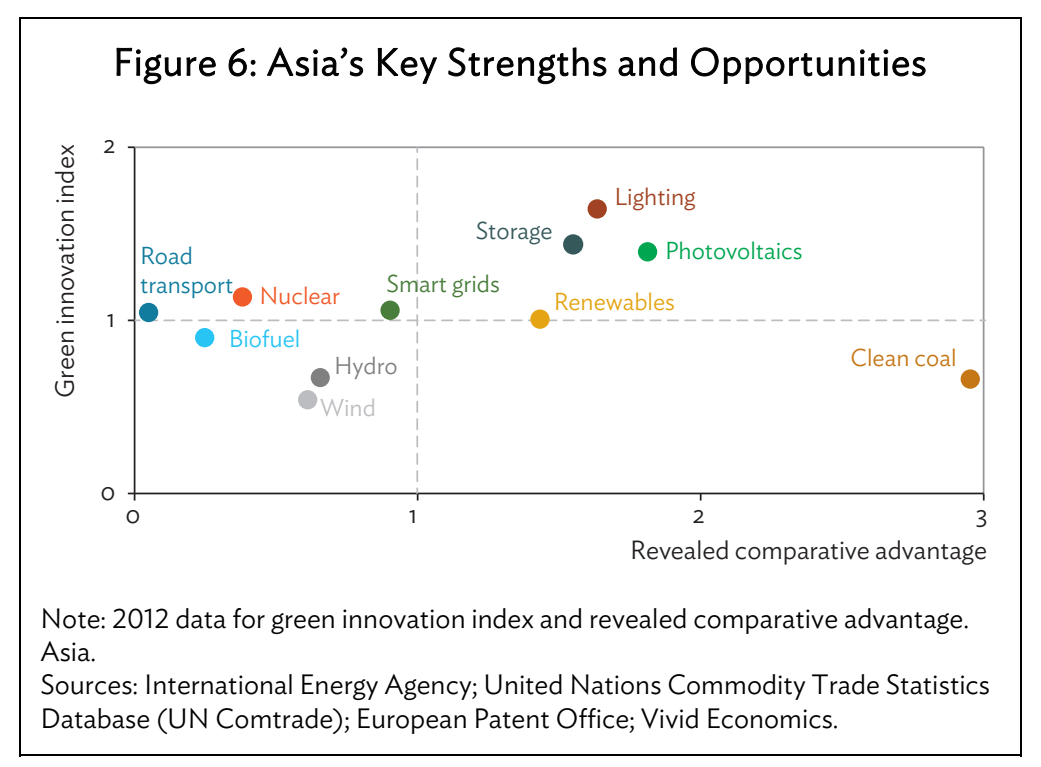

However, there is a threat associated with being in the bottom right quadrant of Figure 5 . As an exporter and not an innovator, a country is exposed to the risk of market-changing innovations from elsewhere in the world, which can render current production redundant, all other things being equal. To mitigate this threat, a country can either start engaging in frontier innovation or ensure that appropriate technology transfer policies are in place. The risk is lower for technologies that are nearing the end of their innovation chain (see Figure 7 for the PRC's threats).

Key opportunities for Asia include nuclear power, efficient road transport, and smart grids. These technologies are predicted to have large markets by 2050 according to the International Energy Agency's 2-degree scenario. Asia is leading the market transformation in some of these areas, particularly nuclear where the Government of the PRC has put in large sums of investment. Given its disposition for manufacturing, Asia could leverage its position as an innovator to engage in exporting greater quantities of these technologies.

Asia is weaker in wind and hydro than Europe, but our data do not show domestic scale, where Asia's wind sector is large. As explained in the country profiles, the PRC's wind sector has experienced phenomenal growth, and India has a strong RCA and has engaged in process innovation.

There appear to be potential rivalries between Asian countries for future market share. For example, Japan and the Republic of Korea are likely to compete to gain global market share in smart grids, while the PRC is likely to compete with Japan in nuclear energy due to its high levels of innovation and ambitions to export its nuclear technology.

Overall, these results show that economies in developing and developed Asia are well placed to serve new markets created by climate change mitigation. With the right policy mix, Asia could consolidate its position as a top innovator and exporter in key CCMTs. For technologies where Asia 
does not have a specialization, it can either seek to develop it, if prudent, or, in the case of limited resources and capacity, ensure that trade and technology transfer help facilitate the adoption and diffusion of technologies. There are immense gains from technology transfer, knowledge sharing, and trade not only globally but also within the region.

\section{People's Republic of China}

Economic growth has severely compromised the quality of the environment in the PRC. The country's air, soil, and water quality have degraded to alarming levels in recent years. In 2014, the Ministry of Environmental Protection announced that 44\% of the PRC's groundwater was deemed to be of poor quality, $20 \%$ of farmland was contaminated, and that only three out of 74 monitored cities met official air quality standards in 2013. Underpinning these trends is the fact in 2006 the PRC became the world's largest $\mathrm{CO}_{2}$ emitter (Ho and Wang 2014).

The PRC government has made substantial efforts to control pollution. Officials have committed to peak emissions by 2030. In the 12th Five-Year Plan, the government pledged to spend $\$ 275$ billion over the next 5 years to clean up the air and $\$ 333$ billion for water pollution. According to the plan, three out of the seven strategic industries for investment are green: alternative energy, alternative fuel cars, and energy saving (Jacobs 2012).

The PRC's success is particularly visible in renewables. It has achieved the world's largest wind power capacity, has plans to triple solar power, and multiply nuclear capacity sixfold by 2020 (Ho and Wang 2014). Officials have committed to ensuring renewables account for $20 \%$ of the energy mix by 2030 and aim to reduce carbon intensity by 17\% (Albert and Xu 2016).

The PRC is a leading exporter in CCMTs. As Figure 7 shows, the PRC accounts for a fifth of global CCMT exports and this extends beyond its share of total global exports, which is $13 \%$.

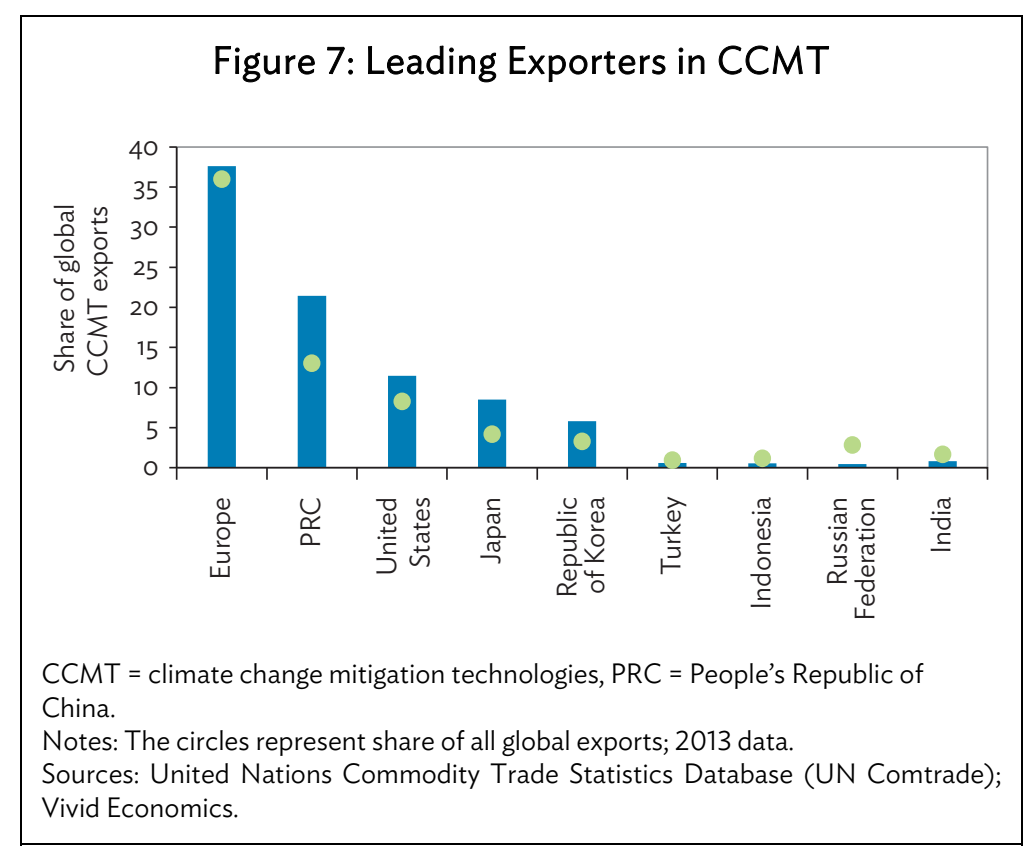


The analysis of the PRC's GII and RCA scores (Figure 8) suggests that it is an exporter more than it is an innovator of CCMTs. The PRC is an early adopter of CCMTs and engages in high levels of manufacturing and export. In the PRC's case, it is especially important to note that the GII and RCA are only two dimensions of a multidimensional green economy. Again, an important third dimension is the domestic scale which is not represented in this analysis. There are agglomeration benefits associated with domestic scale that are likely to be significant in the PRC.

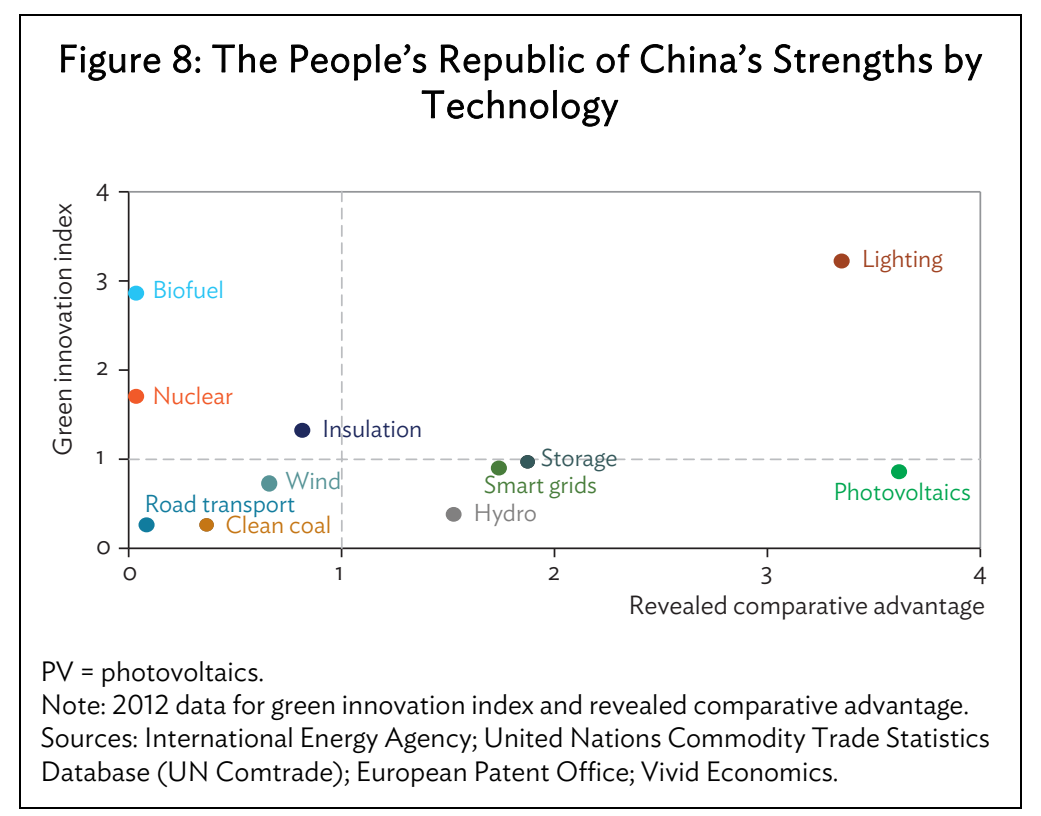

However, unlike developed Asian countries such as Japan and the Republic of Korea, the PRC is not yet a frontier innovator in CCMTs. The PRC's main strength is in efficient lighting where it has both an innovation and export specialization.

An opportunity is nuclear power, where the PRC can potentially overtake Japan. The PRC has high levels of innovation in nuclear technology but still needs to consolidate its export position. Nuclear is one of the most difficult technologies in which to compete given its complexity and high up-front costs. Given the PRC's size, government support, and access to capital, it could be well placed to lead in this area.

Overall, the GII and RCA statistics suggest that innovative capacity will not be an immediate driver of future success in the green economy. If the PRC is successful in the green economy, this may rely more on the benefits of returns to scale rather than innovation. On some technologies, such as wind, these data may not give a clear picture of true success, given that wind is deployed widely domestically, where the PRC is the largest market globally. To safeguard its market against transformative innovations from elsewhere in the world, the PRC has to stay on top of recent technological developments, start engaging in technology rather than process innovation, and ensure appropriate technology transfer policies are in place.

\section{Philippines}

As a highly vulnerable country to climate change and climate-related disasters, the Government of the Philippines has acknowledged the importance of tackling climate change. The Climate Change Commission created the National Framework Strategy on Climate Change for 2010-2022 which places 
great emphasis on adaptation, with reference to mitigation as a function of adaptation. The commission has also mandated government agencies to track climate change expenditures to monitor progress.

The Philippines excels in a number of low-carbon metrics. According to BIS 2015 data, the Philippines has the highest level of LCEGS sales as a percentage of GDP in Asia. OECD data show that it also excels in $\mathrm{CO}_{2}$ productivity since it has the highest GDP per unit of energy-related $\mathrm{CO}_{2}$ emissions in Asia (Figure 9). The Philippines also scores well on energy productivity, where it comes in second place after Viet Nam. This is likely due to the fact that the Philippines generates $52 \%$ of its energy from renewable energy, that is, primarily geothermal and hydropower (Nachmany et al. 2015).

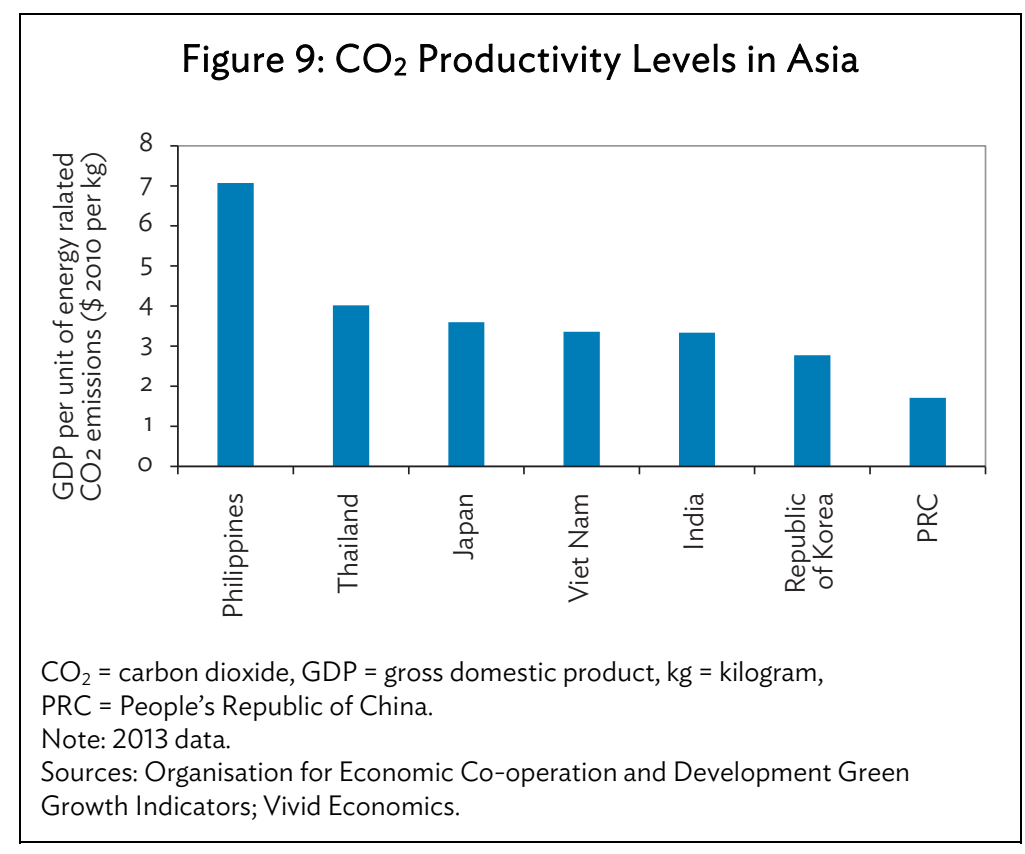

Overall, the Philippines enjoys a comparative advantage in a few CCMTs. According to our analysis, the Philippines has a comparative advantage in efficient lighting, photovoltaics, and energy storage. All of these technologies enjoy a share in the country's exports which is up to 5 times higher than their average share in global exports.

Where the Philippines has room for improvement is in innovation. Data from the European Patent Office reveal that the country engages in almost zero high-value patenting activity in the area of climate change mitigation. Overall, the analysis demonstrates that the Philippines has potential to capture value from export in the green economy but not design. It will be relatively dependent on international trade and assistance to obtain the latest CCMTs.

In terms of policies, maintaining forest cover is a key priority in the Philippines. The Philippines has been proactive in maintaining existing forest and restoring lost carbon sinks from degraded or cleared forest (Asian Development Bank Institute 2012). Additionally, the Philippines is among the eight core implementing countries of the Wealth Accounting and Valuation of Ecosystem Services partnership by the World Bank. Ecosystem accounting is taking place in Laguna Lake Basin and Southern Palawan. While the country does not innovate in CCMTs, it appears to be engaging in other aspects of green growth such as the protection of natural capital. 


\section{Viet Nam}

Viet Nam is one of the fastest-growing economies in Southeast Asia with energy demand expected to triple in the next 10 years. Viet Nam's current growth trajectory and National Master Plan for Power Development for 2011-2020 include plans for large increases in carbon-intensive coal-fired power plants.

Lying in the tropical cyclone belt, Viet Nam is vulnerable to extreme weather events. The government has acknowledged this and made adaptation a key priority. There is a lower emphasis on mitigation although policy documents exist.

The data show that Viet Nam has almost no high-value patents in CCMTs. However, it enjoys a comparative advantage in wind, energy storage, and biofuels. This, in part, reflects government efforts to encourage the development of wind and biofuels (Nachmany et al. 2015). Currently, Viet Nam is not well placed to capture value from the green economy.

The country has the highest share of renewables in energy generation in our sample (Figure 10). However, this is mainly due to its large hydropower potential, which is often developed in forested areas causing deforestation. As such, its sustainability is unclear.

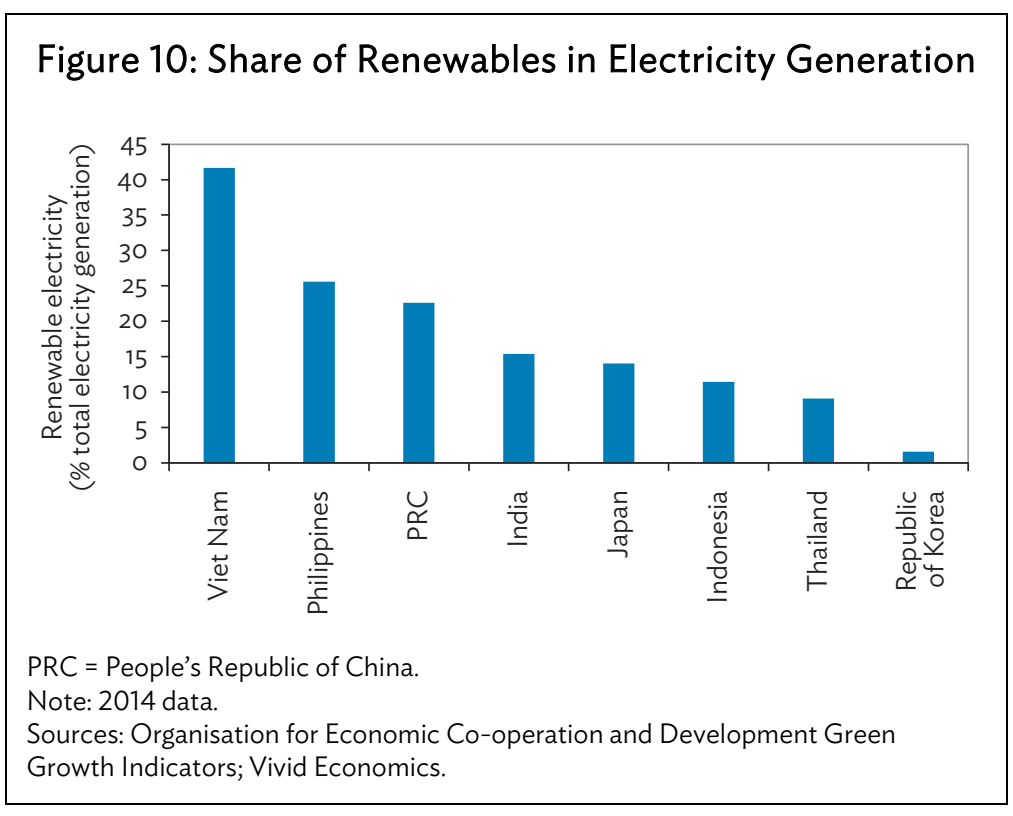

Viet Nam's National Green Growth Strategy (2012) sets out objectives toward a green economy, energy efficiency, GHG reduction, and improvement of living standards (Nachmany et al. 2015). Initiatives include green city planning. Cities such as Ho Chi Minh are planned as compact communities so that less energy is required in transportation. However, lack of access to finance is a key barrier in energy development (Asian Development Bank Institute 2012). The strategy also includes changes to the fuel structure in industry and transport and an increase in the proportion of new and renewable energy sources. However, it is unclear whether the objectives in the document are in line with the National Master Plan for Power Development. It seems that increase in coal may take precedence. 


\section{Indonesia}

Indonesia is one of the largest GHG emitters in the world, in absolute terms, due to high levels of deforestation. Approximately $80 \%$ of GHG emissions result from deforestation and degradation. Moreover, $95 \%$ of Indonesia's energy supply is made up of fossil fuels. Government efforts have been made to tackle climate change but fall short of what is needed. Key initiatives are embodied in decrees and regulations passed by ministries rather than parliamentarians, which means that they are less effective given the hierarchy of Indonesian legislation (Nachmany et al. 2015).

Our analysis reveals a relatively weak position in the green economy. Indonesia enjoys neither any strong comparative advantages nor an innovation specialization in any CCMT. European Patent Office data show next to no patenting activity, and Indonesia accounts for only $0.5 \%$ of global CCMT exports. With low innovation and export activity, Indonesia is poorly placed to capture value from the green economy. However, the country's natural endowments and capacity for geothermal development suggest that there is a latent potential, which needs to be harnessed through effective policy.

The country's dependence on fossil fuels is exacerbated by its electricity subsidy system, which results in an implicit negative carbon price for coal (OECD 2014). Electricity subsidies amount to around $8 \%$ of total government expenditure (OECD 2015). While efforts have been made to phase out fossil fuel subsidies, much more remains to be done. Indonesia has $40 \%$ of the world's total geothermal energy reserves. However, geothermal energy remains largely underdeveloped and renewables account for a mere $5 \%$ of the country's energy mix.

Top priorities for Indonesia include setting prices right to correct market distortions and putting in place enabling policies to tap into its vast geothermal reserves in order to develop a CCMT specialization.

\section{India}

India is one of the world's largest GHG emitters with a strong expected growth in emissions. However, in recent years, due to pressures including dangerously high levels of air pollution and a shift in government thinking, India has become increasingly open to the idea of unilateral action against climate change. Given its large dependence on rain-fed agriculture, India is also highly exposed to the risks of climate change.

In 2008, India released its National Action Plan on Climate Change with eight missions that target solar power development, energy efficiency, reforestation, and skills development. Targets within the plan include 2 gigawatts of off-grid solar plants and 20 million solar lighting systems. The government plans to develop 60 cities as solar cities during the 11th Five-Year Plan period and include more in the 12th plan. India's solar auctions have also achieved among the world's lowest bids at 6 cents per kilowatt-hour.

European Patent Office data for India were not sufficiently robust, so we did not attempt to calculate the GII. However, according to OECD data, India has been increasing its share of green innovation (Figure 11) and has developed a relative advantage in environment-related technologies. The OECD monitors this through a metric called revealed technology advantage, which takes a country's share of patents in a particular technology and divides that by the country's share in all 
patent fields. This is similar to the GII in that a ratio greater than 1 reveals an innovation specialization. In 2012, India had a revealed technology advantage of 1.27 in environment-related technologies.

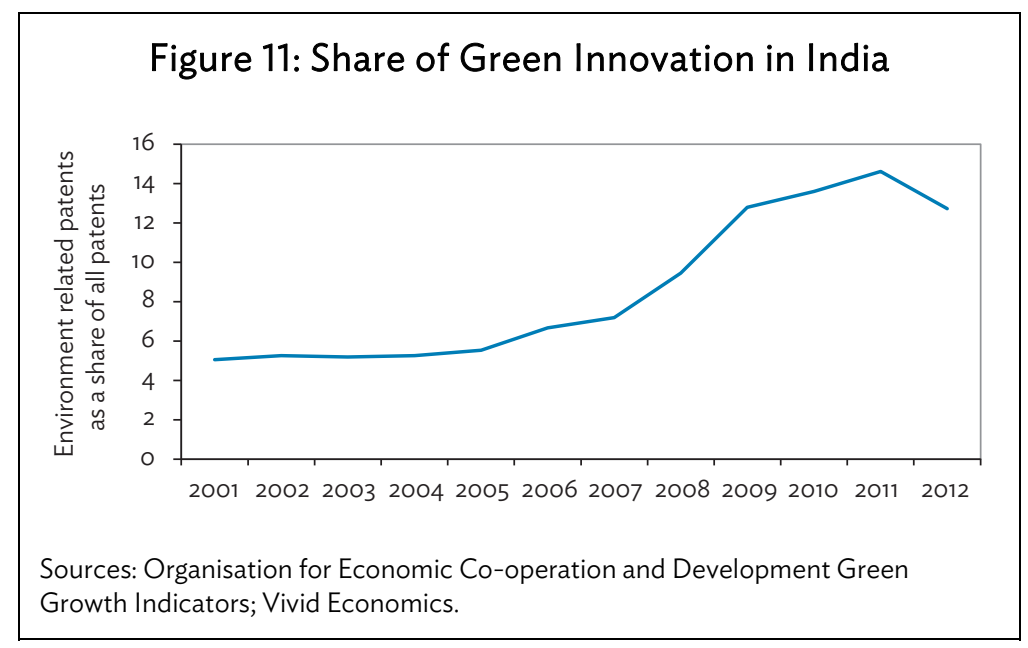

It should also be noted that patent data may not capture the full extent of CCMT innovation in India. India is known to undertake incremental innovation that adapts technologies to the local context and develops new products that are suitable for the poor. A large part of this trend is "frugal innovation" whereby Indians reverse-engineer technologies to keep the essentials and reduce costs. This often makes technologies more environment friendly by cutting excess. An example is low-cost refrigerators that do not have a freezer or solar-powered automatic teller machines.

Our analysis shows that India has a comparative advantage in wind and smart grid technologies. In the area of wind, India undertakes process innovation by adapting European turbines to the Indian context, where wind speeds are lower. India may also be on track to developing its solar potential due to strong government support, natural solar endowments, and high levels of competition in the space.

Despite the progress, India still lags behind comparator nations such as the PRC and its position on CCMT exports is weak. Unlike the PRC, India does not have a big base of CCMT manufacturing to build on, and this is in part because India's policy shift toward green growth came later. Indian policy makers also have to take a critical decision on coal and decide how to phase out dependence on dirty energy without compromising on other social development objectives. Overall, there are signs of progress on both the innovation and export front, but the larger abatement story hinges on choices related to the role of coal in electricity generation.

\section{Republic of Korea}

The Republic of Korea was one of the first countries in Asia to announce a green growth plan. The country's natural asset base was under consistent strain with depleting water resources and forest cover. However, the Government of the Republic of Korea committed to address this threat through its National Strategy for Green Growth (2009-2050) wherein it stated that green growth is a strategic priority (Ministry of Government Legislation 2010). Consequently, research and development (R\&D) expenditure related to green growth and share of green overseas development assistance grew rapidly. According to the OECD and Statistics Korea, the Republic of Korea's economy is becoming greener (Statistics Korea 2012). Indicators show that environmental and resource productivity, including $\mathrm{CO}_{2}$ 
emissions productivity, energy productivity, and domestic material consumption, have improved since 2000. Government efforts also show up in our data since the Republic of Korea has strengths in multiple technologies (Figure 12).

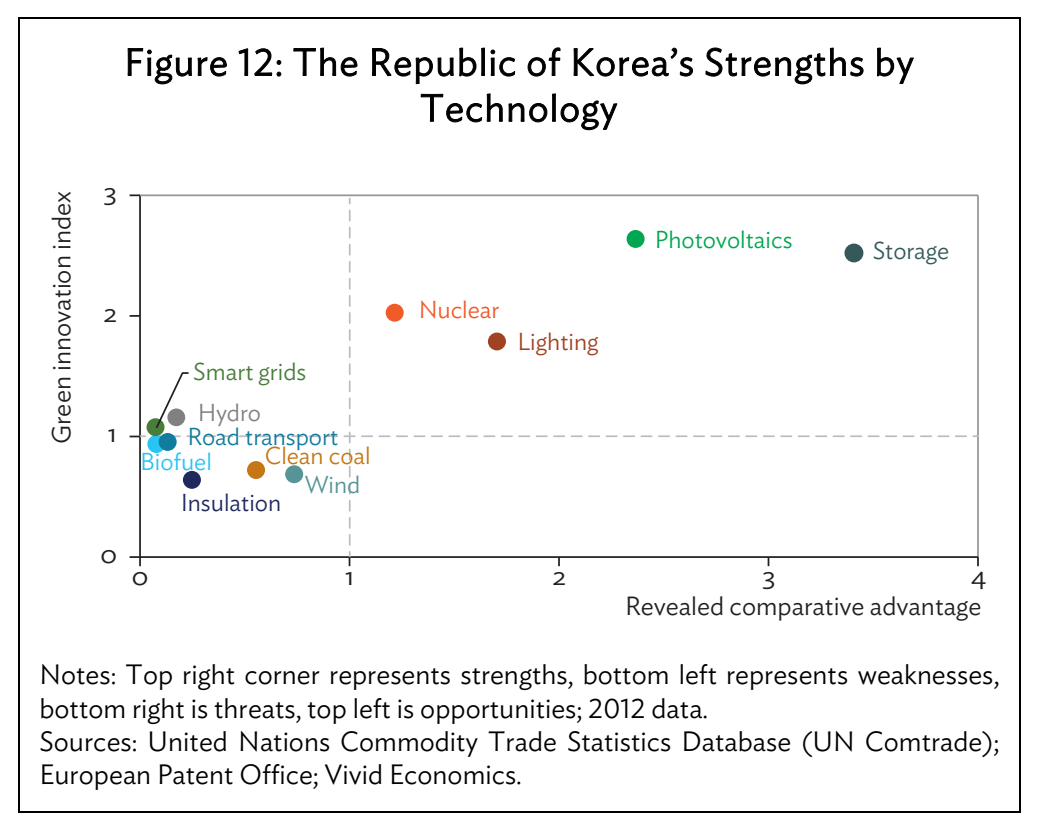

The Republic of Korea has a strong RCA and GII in several technologies, demonstrating that the country has directed its efforts strategically. Our analysis shows that it is well placed to take advantage of the future green economy across nuclear, photovoltaics, lighting, and storage. The Republic of Korea is particularly competitive in energy storage and is poised to have one of the world's largest energy storage systems. Both the Republic of Korea and Japan have strong innovation for smart meters, but are yet to develop their export markets, suggesting that they may be future competitors in this technology.

Compared to other countries, the data suggest that the Republic of Korea may have a coordinated focus on innovating products where it has an existing export advantage (or vice versa), thus playing to its strengths. Other Asian countries could learn lessons from the Republic of Korea's ongoing green economy transition.

\section{Japan}

Japan has made substantial headway toward decoupling growth from emissions. During 2002-2007, emissions from traditional air pollutants such as sulfur oxides and nitrogen oxides fell despite a growing economy, indicating that Japan had embarked upon the path of decoupling emissions from GDP growth. Similarly, Japan's energy intensity as measured by energy supply per unit of GDP has been in steady decline (Capozza 2011).

Japan's 2009 growth strategy placed a strong emphasis on innovation and green growth. Key priorities were renewable energy, green innovation, and zero emission residential and commercial buildings (Capozza 2011). Japan's overarching green economy objective for 2020 is to generate market value of over $¥ 50$ trillion and 1.4 million jobs in environment-related sectors. It also aims to reduce global GHG emissions by promoting Japanese technology worldwide. 
Japan files the highest number of high-value CCMT patents in Asia, with a focus on transport (Figures 13 and 14). This is unsurprising given that Japan is already a leading car manufacturer (alongside the US and Western Europe) and since Toyota has a large line of hybrid vehicles. In addition to transport, there are high levels of innovation in energy storage and buildings.

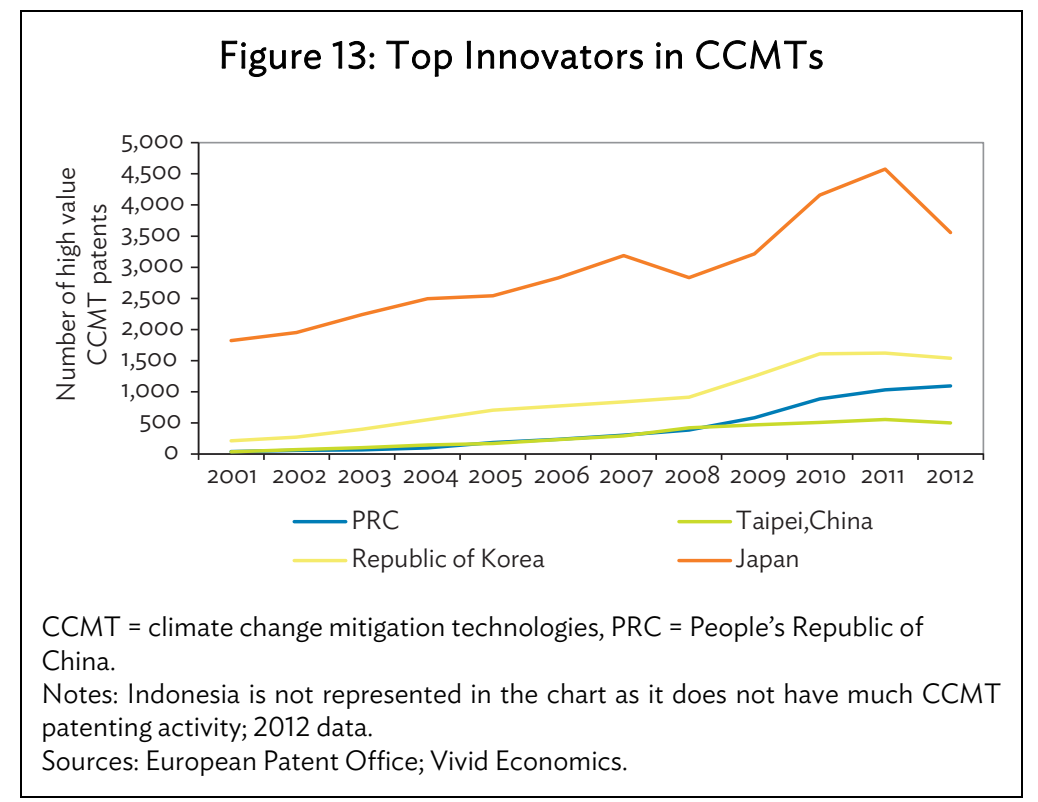

Figure 14: Japanese Climate Change Mitigation Patents

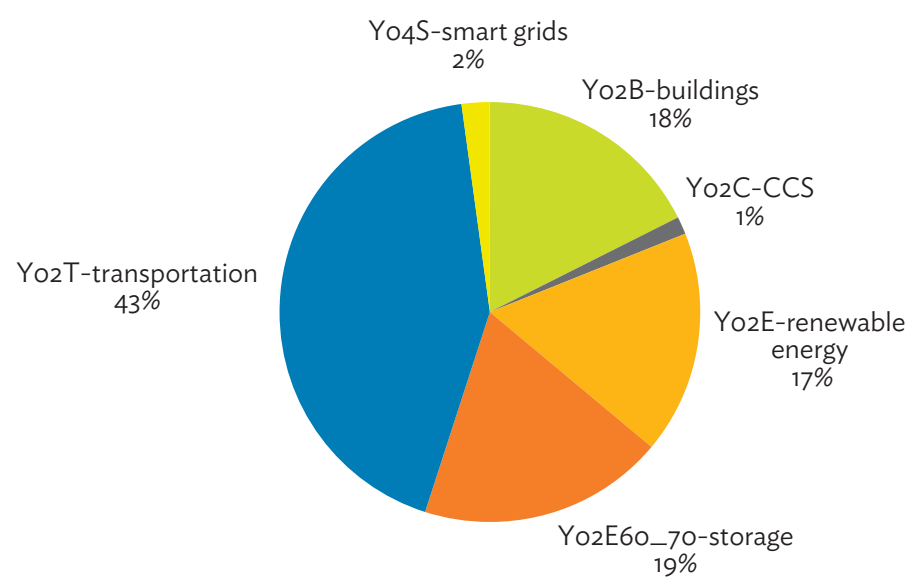

Note: 2012 data.

Sources: European Patent Office; Vivid Economics.

Based on an assessment of Japan's GII and RCA across CCMTs, the country appears well poised to capture future value from green transport. Japan's share of transport exports is 7 times higher than the world average share, indicating a strong and highly entrenched comparative advantage (Figure 15). Japan also has the opportunity to develop its smart grid sector by focusing on capturing global market share through exports and building manufacturing capacity. However, as mentioned earlier, it faces competition from the Republic of Korea and must move quickly. Japan's nuclear 
technology is at risk of being overtaken by that of the PRC due to Japan's relatively low levels of innovation and the effects of the Fukushima incident on public opinion for nuclear. Overall, while Japan is in a strong position for green growth and has consolidated its position in green transport, it must still ensure that aging industries are well prepared for competition from developing Asia.

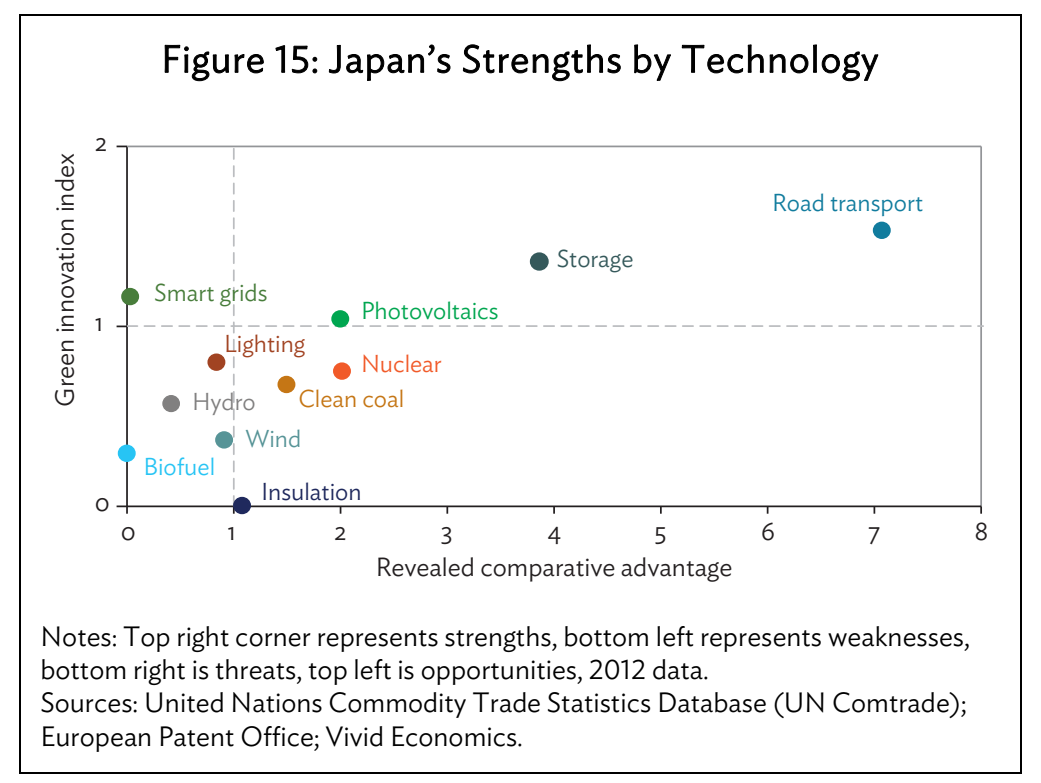

\section{POLICIES FOR PURSUING GREEN GROWTH}

This section discusses the policies Asian countries may need to consolidate their position in the green economy and take advantage of future opportunities. We review policies that refer specifically to the creation of green comparative advantage and innovation specialization, as well as the wider set of measures needed to ensure Asia's overall transition to a green, low-carbon economy.

Although our framework focuses on two dimensions of the green economy transformation, it can help inform decisions on innovation and industrial policy. All countries should not necessarily attempt to maximize their GII and RCA scores, that is, every country need not be a top innovator and exporter in all technologies. What is more important is that countries have a strategic approach toward which technologies to support. Countries should be careful to not underinnovate in a technology where they have an existing comparative advantage and which may serve as a critical part of their green growth agenda.

Selecting which technologies to develop an innovation and trade specialization in is difficult but may be informed by the following two considerations:

(i) Where does a country have an existing innovation or export advantage?

(ii) Which technologies carry immense spillover benefits to its economy?

Our charts can help answer the first point. To answer the second point, countries must carefully consider the structure of their economies and the connections between different industries. 
Governments could support industries that have strong backward and forward linkages with other markets so as to enable a wider green economy transformation. ${ }^{2}$ Hidalgo et al. (2007) argue that an activity such as supporting electric vehicles can have a host of spillover benefits and can create a green transport ecosystem since electric engines can be used in other modes of transport, batteries have wider applications, and charging stations help create the necessary infrastructure.

For these selected sectors, an economy may wish to develop an innovation specialization (i.e., move up the $y$-axis) and a trade specialization (i.e., move across the $x$-axis). In a setup with no intervention, market forces would determine the position of economies on both the $x$ and $y$ axes. However, given market failures as set out in section I, innovation is underprovided and governments are often heavily involved in the delivery of R\&D. Similarly, for exports, some economies may wish to promote export activity in CCMTs that have large positive externalities and help mitigate global $\mathrm{CO}_{2}$ emissions. In other words, governments can strategically choose innovation and industrial policy across key CCMTs to help mitigate climate change and internalize externalities.

\section{Instruments to Develop a Specialization in CCCMTs and Achieve Growth}

Due to market failures that include limited access to finance, distorted prices, information asymmetries, and coordination failures, some Asian economies have found it difficult to harness their potential in CCMTs. According to the World Bank (2012), "many developing countries have natural endowments that create a potential comparative advantage in green activities" but have been unable to capitalize on the benefits. To allow low-carbon growth to take off, policy makers will have to tackle a range of market imperfections, policy failures, and behavioral challenges.

The low-carbon economy in Asia needs enabling conditions to facilitate greater private sector involvement. Research shows that higher levels of competition can result in an incremental increase in the profits from innovation (Aghion et al. 2005), thereby incentivizing more innovation. ${ }^{3}$ Until the 1990s, CCMT innovation was mostly driven by energy prices, but, since then, environmental policies have accelerated its pace (Dechezleprêtre et al. 2011). The government therefore has a role to play in supporting low-carbon markets by putting in place enabling policies.

Crucially, it is up to domestic policy to help develop CCMT specializations locally. While international policies are important, their marginal effect on local innovation improvements can be up to 12 times lower than the effect of domestic policies (Dechezleprêtre et al. 2011).

Methods to correct market failure include innovation and industrial policy. As the World Bank (2011) reiterates, "while the idea of developing green industries is appealing, it has little chance of succeeding unless structural problems such as regulatory obstacles to the creation of small enterprises and the lack of skilled workers are addressed." In this section, we examine price and nonprice mechanisms to correct for market failure.

2 Products that serve as inputs in a host of other industries and result in the creation of more input industries have strong backward and forward linkages.

3 Aghion et al. (2005) highlight that there may be an inverted- $U$ relationship between competition and incremental profits from innovation. However, in developing Asia's case, due to an underdeveloped low-carbon economy, it is likely that countries are below the optimum level of competition. 


\section{Price Mechanisms}

Chief among the market imperfections that prohibit growth is the climate change externality, that is, the inaccurate pricing of GHG emissions. Such externalities can be internalized by setting appropriate prices through taxation or subsidy schemes. When done correctly, empirical evidence shows that this method provides the optimal solution. Carbon pricing has incentivized emission reductions with very limited effects, so far, on competitiveness. Moreover, evidence from the auto industry shows that "firms tend to innovate relatively more in clean technologies when they face higher tax-inclusive fuel prices" (Aghion et al. 2012). Therefore, carbon taxation also helps spur green innovation, which carries significant spillover benefits in the form of facilitating a green economy transformation.

Perhaps the most egregious policy distortion is the continued subsidization of fossil fuels and the underpricing of energy (Coady et al. 2015). As a first and necessary step, countries such as Indonesia should remove subsidies that support dirty energy and distort the market toward carbonintensive production processes. Thereafter, governments can explore mechanisms to support clean technologies such as subsidies for renewables or electric vehicles.

\section{Nonprice Mechanisms}

However, prices are difficult to pin down accurately and are not always sufficient for delivering innovation and investment in long-lived investments without complementary, nonmarket measures. Nonprice mechanisms need to focus on three aspects: (i) regulation, (ii) skills, and (iii) financing.

In terms of regulation, policies to encourage technology transfer are important especially in light of the fact that not every country will become a frontier innovator in CCMTs. Research shows that lax intellectual property (IP) regimes have a strong negative impact on the international diffusion of patented knowledge (Dechezleprêtre, Glachant, and Ménière 2011). A policy objective may be to negotiate technology transfer arrangements such that IP holders feel comfortable sending their technologies to developing nations in Asia. A combination of international negotiation and adjustment of national IP regimes should be considered to ensure that appropriate levels of technology diffusion.

Government support for R\&D toward green innovation may also be needed in the initial stages of CCMT development. Low-carbon innovations generate technological improvements in a wide range of sectors, similar to the way that information technology innovations benefit sectors other than computing. This can help to offset the costs of climate change mitigation and generate economic growth. Regulation such as efficiency standards, planning rules, and building codes can also help spur green innovation.

The government may also need to intervene to address coordination failures and play its role as a market maker or provider of critical infrastructure. For example, the development of renewables technologies may rely on the rollout of transmission lines or a supply chain to provide parts. Government intervention may be justified here to ensure sufficient and coordinated provision of goods to enable innovation.

In terms of skills, countries need to focus on the direction of their green growth and ensure that they have a sufficiently skilled base resources to draw from. Countries such as India can leverage their base of skilled software professionals to further develop and consolidate their comparative advantage in smart grid technology. Other countries, such as Indonesia, that currently do not have a comparative advantage in any CCMT can strategically pick an area for development, such as 
geothermal energy, and ensure that their education system has courses to train people in areas associated with this technology's development. A two-step process would be to define a green growth strategy and pick areas for development and then put in place measures to ensure that the appropriate skills and training programs are in place.

Finally, policies to remove financial barriers are essential for the takeoff of growth. Examples of effective policies include innovation funds. Competition for funds can provide a pull mechanism for R\&D in early-stage technologies. Other measures include payment-by-results schemes or green bonds.

An essential part of the overall policy mix is strategies to ease the cost of transition, by supporting labor mobility and creating the industrial champions of the new green economy. Structural economic change will, by its very nature, involve disruption. One key concern is structural rigidities in the labor market, both in terms of labor mobility and wages, which could lead to short-term unemployment (Bowen and Kuralbayeva 2015). There are also rigidities in the capital stock. Carbonintensive capital is often long-lived and assets might get stranded unless investment decisions are sufficiently forward looking. Finally, there is inertia associated with innovation, which appears to be heavily path dependent (Aghion et al. 2014). For these reasons, phased approaches and methods to ease the cost of transition will be important to avoid political backlash.

\section{CONCLUSIONS}

Our analysis has shown that, as a whole, Asia is on track to capture value from the design and export of key CCMTs such as energy storage, photovoltaics, and efficient lighting. However, there is room for growth by developing specializations in additional CCMTs, ensuring the green economy transformation is occurring equally across all Asian countries, and further advancing policies to enable this transformation (Figure 16).

It is important to emphasize that our analysis focuses on frontier innovation and export specialization, which are just two dimensions of a multidimensional green economy transformation. Nevertheless, they are important dimensions in light of the value that accrues from IP rights and export activity, and because of the transformative nature of frontier innovation.

While some Asian countries have achieved impressive scale in the deployment of climate change mitigation technologies (the PRC), others are frontier innovators (the Republic of Korea and Japan). Much of developing Asia (India, the PRC, Viet Nam, and the Philippines), while not currently engaged in high levels of frontier innovation, has an RCA in key low-carbon technologies. For example, India has a comparative advantage in smart grids and wind, while the Philippines has it in efficient lighting and photovoltaics. Most notably, the PRC has among the highest shares of photovoltaics in its export basket and has a high comparative advantage in several climate change mitigation technologies. Several of these countries also engage in incremental or process innovation which is not captured in our data. For example, India has adapted European wind turbines to account for lower wind speeds, and the PRC has innovated to bring down the cost of photovoltaics manufacture. Other countries, such as Indonesia, have developed neither an innovation nor export specialization in climate change mitigation technologies, and have room for improvement. 


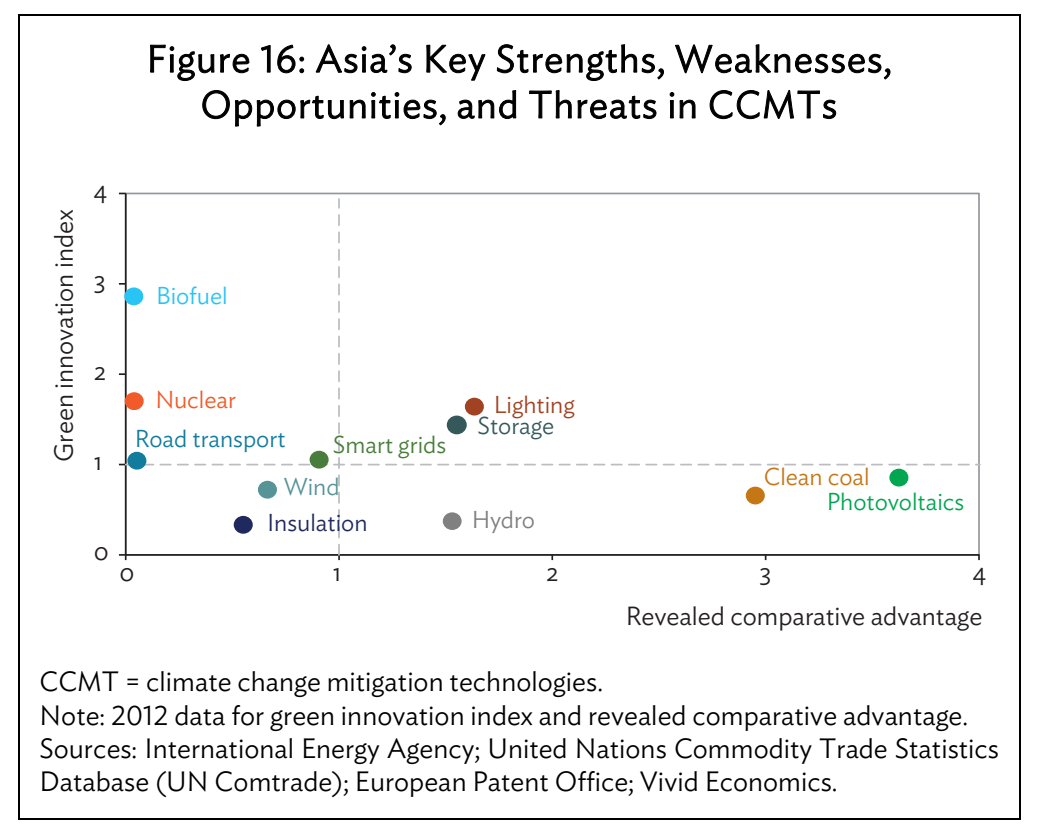

It is not necessarily the case that all countries should attempt to maximize their levels of innovation and export in all technologies. What is important is that countries have a strategic approach on which technologies and sectors to pursue, and are not underinnovating in a technology in which they inherently have a competitive advantage and/or which carries immense spillover benefits for the economy.

While Asia has the largest value of green sales relative to other continents, its regional disparities are stark. Within Asia, the PRC has the largest value of green sales and is second globally only to the US. Other developing Asian countries, such as India, Indonesia, Viet Nam, and the Philippines, have much smaller economies. Such countries' green patenting activity is nascent and cannot compare to that of Asia's top innovators, Japan and the Republic of Korea.

However, Asia has much to gain from further regional integration. Developing Asian countries need not only rely on Europe and North America for CCMT trade, information sharing, and technology transfer. Within Asia trade and integration can help diffuse CCMT technologies throughout the continent to the benefit of both top innovators and developing countries. Research has shown that trade with developing countries contributes positively to the green economy transformation. By increasing within Asia trade of CCMTs, Japan and the Republic of Korea can create wider markets for their technology and access the rich natural resources and human capital that developing countries have to offer. In return, developing countries can learn from top innovators in order to develop their own local industries. As with all other goods, the benefits of trade and regional integration apply to the economy.

An aspect that was omitted from this study and could warrant further development is the role of domestic market size and agglomeration in the future potential of the green industry. The authors leave that for future research. 


\section{REFERENCES}

Acemoglu, Daron, and Joshua Linn. 2004. "Market Size in Innovation: Theory and Evidence from the Pharmaceutical Industry.” The Quarterly Journal of Economics 119 (3): 1049-90.

Aghion, Philippe, Nick Bloom, Richard Blundell, Rachel Griffith, and Peter Howitt. 2005. "Competition and Inovation: An Inverted-U Relationship." The Quarterly Journal of Economics 120 (2): 70128. doi:10.1093/qje/120.2.701

Aghion, Philippe, Antoine Dechezleprêtre, David Hemous, Ralf Martin, and John van Reenen. 2012. "Carbon Taxes, Path Dependency and Directed Technical Change: Evidence from the Auto Industry." Grantham Research Institute on Climate Change and the Environment and Centre for Climate Change Economics and Policy Working Paper No. 120.

Aghion, Philippe, Cameron Hepburn, Alexander Teytelboym, and Dimitri Zenghelis. 2014. "Path Dependence, Innovation and the Economics of Climate Change." Policy Paper . Grantham Research Institute on Climate Change and Centre for Climate Change Economics and Policy.

Albert, Eleanor, and Beina Xu. 2016. "China's Environmental Crisis.” Council on Foreign Relations, January 18. http://www.cfr.org/china/chinas-environmental-crisis/p12608

Asian Development Bank Institute. 2012. Policies and Practices for Low-Carbon Green Growth in Asia. Tokyo. http://www.adb.org/sites/default/files/publication/29767/policies-green-growth-asiahighlights.pdf

Barbier, Edward B. 2010. "Green Stimulus, Green Recovery and Global Imbalances." World Economics $11(2): 1-27$.

Bowen, Alex, Chris Duffy, and Sam Fankhauser. 2016. “Green Growth' and the New Industrial Revolution." Policy Brief.Grantham Research Institute on Climate Change and the Environment and Global Green Growth Institute.

Bowen, Alex, and Sam Fankhauser. 2011. "The Green Growth Narrative: Paradigm Shift or Just Spin?” Global Environmental Change 21 (4): 1157-59.

Bowen, Alex, and Cameron Hepburn. 2014. "Green Growth: An Assessment." Oxford Review of Economic Policy 30 (3): 407-22. doi:10.1093/oxrep/gru029

Bowen, Alex, and Karlygash Kuralbayeva. 2015. "Looking for Green Jobs: The Impact of Green Growth on Employment." Policy Brief. Grantham Research Institute on Climate Change and the Environment and Global Green Growth Institute.

Bowen, Alex, and Nick Stern. 2010. "Environment Policy and the Economic Downturn." Oxford Review of Economic Policy 26 (2): 137-63.

Capozza, Ivana. 2011. “Greening Growth in Japan.” OECD Environment Working Paper No. 28.

Coady, David, Ian Parry, Louis Sears, and Baoping Shang. 2015. "How Large Are Global Energy Subsidies?" IMF Working Paper WP/15/105. 
Dechezleprêtre, Antoine, Matthieu Glachant, Ivan Haščič, Nick Johnstone, and Yann Ménière. 2011. "Invention and Transfer of Climate Change Mitigation Technologies: A Global Analysis." Review of Environmental Economics and Policy 5 (1): 109-30.

Dechezleprêtre, Antoine, Matthieu Glachant, and Yann Ménière. 2011. "What Drives the International Transfer of Climate Change Mitigation Technologies? Empirical Evidence from Patent Data." Grantham Research Institute on Climate Change and the Environment. Working Paper No. 14.

Dechezleprêtre, Antoine, and Ralf Martin. 2010. "Low Carbon Innovation in the UK: Evidence from Patent Data." Policy Paper. Grantham Research Institute on Climate Change and Environment Centre for Climate Change Economics and Policy.

Dechezleprêtre, Antoine, Ralf Martin, and Myra Mohnen. 2013. "Knowledge Spillovers from Clean and Dirty Technologies: A Patent Citation Analysis.” CEP Discussion Paper No. 1300.

Department for Business, Innovation and Skills (BIS). 2015. "Low Carbon and Environmental Goods and Services 2011 to 2012: Data."

https://www.gov.uk/government/publications/low-carbon-and-environmental-goods-andservices-2011-to-2012 (accessed August 15, 2016).

European Patent Office. http://be.espacenet.com/ (accessed August 15, 2016).

Fankhauser, Sam, Alex Bowen, Raphael Calel, Antoine Dechezleprêtre, David Grover, James Rydge, and Misato Sato. 2013. "Who Will Win the Green Race? In Search of Environmental Competitiveness and Innovation." Global Environmental Change 23 (5): 902-13.

Fouquet, Roger, and Peter Pearson. 2012. "The Long Run Demand for Lighting: Elasticities and Rebound Effects in Different Phases of Economic Development." Economics of Energy \& Environmental Policy 1 (1): 83-100. doi:10.5547/2160-5890.1.1.8

FTSE. 2016. "New Green Revenues Model from FTSE Russel Tracks Global Transition to a Green Economy." FTSE Russell, June 6. https://www.ftserussell.com/files/press-releases/new-greenrevenues-model-ftse-russell-tracks-global-transition-green-economy

Government of Viet Nam. 2012. The Viet Nam National Green Growth Strategy.

Green Growth Knowledge Platform. 2013. "Moving towards a Common Approach on Green Growth Indicators." Green Growth Knowledge Platform Scoping Paper.

Hartwick, John. 1977. "Intergenerational Equity and the Investing of Rents from Exhaustible Resources." The American Economic Review 67 (5): 972-74.

Hidalgo, Cesar, Bailey Klinger, Albert-Laszlo Barabasi, and Riardo Hausmann. 2007. "The Product Space Conditions the Development of Nations. Science 317 (5837): 482-87. doi:10.1126/science.1144581

Ho, Mun, and Zhongmin Wang. 2014. "Green Growth (for China): A Literature Review." Resources for the Future Discussion Paper No. 14-22. doi:10.2139/ssrn.2537838 
Hotelling, Harold. 1931. "The Economics of Exhaustible Resources.” Journal of Political Economy 39 (2): 137-75. doi:10.1086/254195

HSBC. 2009. "A Climate for Recovery: The Colour of Stimulus Goes Green.” HSBC Global Research. http://globaldashboard.org/wp-content/uploads/2009/HSBC_Green_New_Deal.pdf

International Energy Agency (IEA). http://www.iea.org/statistics/ (accessed August 15, 2016).

Jackson, Tim. 2011. "Societal Transformations for a Sustainable Economy. Natural Resources Forum 35 (3): 155-64. doi: 10.1111/j.1477-8947.2011.01395.x

Jacobs, Michael. 2012. "Green Growth: Economic Theory and Political Discourse." Grantham Research Institute on Climate Change and the Environment Working Paper No. 92.

Klein, Naomi. 2015. This Changes Everything. New York, NY: Simon \& Schuster.

Ministry of Government Legislation. 2010. Framework Act and Its Presidential Decree on Low Carbon, Green Growth in Korea. Seoul: Government of the Republic of Korea.

Nachmany, Michal, Sam Fankhauser, Jana Davidová, Nick Kingsmill, Tucker Landesman, Hitomi Roppongi, Philip Schleifer, Joana Setzer, Amelia Sharman, C. Stolle Singleton, Jayaraj Sundaresan, and Terry Townshend. 2015. The 2015 Global Climate Change Legislation Study: A Review of Climate Change Legislation in 99 Countries. London: Grantham Research Institute on Climate Change and the Environment.

Organisation for Economic Co-operation and Development (OECD). OECD indicators: http://www.oecd.org/greengrowth/greengrowthindicators.htm (accessed August 15, 2016).

1999. The Environmental Goods and Services Industry: Manual for Data Collection and Analysis. Paris: OECD.

2011. Towards Green Growth. Paris.

2014. Towards Green Growth in Southeast Asia. Paris.

2015. OECD Economic Surveys: Indonesia 2015. Paris.

Perez, Carlota. 2002. Technological Revolutions and Financial Capital: The Dynamics of Bubbles and Golden Ages. Cheltenham, UK: Edward Elgar.

Pigou, Arthur C. 1920. The Economics of Welfare. London: Palgrave Macmillan UK.

Schumpeter, Joseph. 1942. Capitalism, Socialism and Democracy. New York: Harper and Brothers.

Solow, Robert M. 1974. "The Economics of Resources or the Resources of Economics." American Economic Review 64 (2): 1-14. doi:10.1080/19390450802504048

Spash, Clive. 2008. "How Much Is That Ecosystem in the Window? The One with the Bio-Diverse Trail.” Environmental Values 17 (2): 259-84. http://www.jstor.org/stable/30302641 
Statistics Korea. 2012. "Korea's Green Growth: Based on OECD Green Growth Indicators." http://www.oecd.org/greengrowth/Korea's GG report with OECD indicators.pdf

Townshend, Terry, Sam Fankhauser, Adam Matthews, Clément Feger, Jin Liu, and Thais Narciso. 2011. "Legislating Climate Change at the National Level." Environment 53: 5-16.

United Kingdom Department for Business Innovation and Skills. 2011. "Low Carbon and Environmental Goods and Services (LCEGS).” https://www.gov.uk/government/uploads/system/uploads/ attachment_data/file/31780/11-992x-low-carbon-and-environmental-goods-and-services2009-10.pdf

United Nations Commodity Trade Statistics Database (UN Comtrade). https://comtrade.un.org/data/ (accessed August 15, 2016).

Wealth Accounting and the Valuation of Ecosystem Services. https://www.wavespartnership.org/

World Bank. 2011. "World Development Indicators." http://data.worldbank.org/data-catalog/worlddevelopment-indicators

2012. Inclusive Green Growth: The Pathway to Sustainable Development. Washington, DC.

— 2013. "The Changing Wealth of Nations." http://data.worldbank.org/data-catalog/wealth-ofnations

World Commission on Environment and Development. 1987. Our Common Future. Oxford, UK: Oxford University Press. 


\section{Green Growth Opportunities for Asia}

Using patent and trade data, this paper analyzes the potential of Asian economies to capture value from the design and export of low-carbon technologies. It identifies technological strengths and weaknesses across nations and finds that overall, Asia has an innovation specialization and revealed comparative advantage in climate change mitigation technologies. This indicates that the continent is well placed to be competitive in the global low-carbon market. Developing Asia already accounts for $22 \%$ of global patents in climate compatible technologies and 35\% of exports. With regional trade and knowledge sharing, Asian countries can further grow their low-carbon economies.

\section{About the Asian Development Bank}

ADB's vision is an Asia and Pacific region free of poverty. Its mission is to help its developing member countries reduce poverty and improve the quality of life of their people. Despite the region's many successes, it remains home to a large share of the world's poor. ADB is committed to reducing poverty through inclusive economic growth, environmentally sustainable growth, and regional integration.

Based in Manila, ADB is owned by 67 members, including 48 from the region. Its main instruments for helping its developing member countries are policy dialogue, loans, equity investments, guarantees, grants, and technical assistance. 